\title{
Diel feeding behavior in the marine copepod Acartia tonsa in relation to food availability
}

\author{
Ann G. Durbin ${ }^{1}$, Edward G. Durbin ${ }^{1}$, Eva Wlodarczyk ${ }^{2}$ \\ ${ }^{1}$ University of Rhode Island, Graduate School of Oceanography, South Ferry Road, Narragansett, Rhode Island 02882, USA \\ ${ }^{2}$ University of Texas Health Science Center at Houston, Department of Pathology, Houston, Texas 77225, USA
}

\begin{abstract}
Diel feeding behavior and gut evacuation rates were investigated in adult female Acartia tonsa, in laboratory experiments at $20^{\circ} \mathrm{C}$ using different concentrations of cultured Thalassiosira weissflogii as food, and in large mesocosms at $\sim 13^{\circ} \mathrm{C}$ using natural plankton as food. Diel feeding pattern was remarkably stable under the different food conditions and temperatures, maintaining about a 3 -fold amplitude in gut contents and feeding rate over the diel period. The diel rhythm was retained even when the copepods were food limited and lost about $20 \%$ body carbon during the course of the $24 \mathrm{~h}$ experiment. The persistence of the diel feeding rhythm in A. tonsa under starvation implies a strong selective pressure, possibly related to predator avoidance. Daily ingestion rates of copepods fed a high

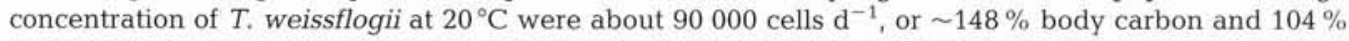
body nitrogen, compared with 74 and $85 \%$ body carbon and 40 and $45 \%$ body nitrogen in mesocosm experiments at $\sim 13^{\circ} \mathrm{C}$ with natural food. Daytime and night-time gut evacuation rates at $20^{\circ} \mathrm{C}$ were not significantly different, indicating that the diel change in gut contents reflects a real change in feeding rate, rather than a change in the instantaneous gut clearance rate. Instantaneous gut evacuation rates were 0.0907 and $0.0894 \mathrm{~min}^{-1}$ in 2 experiments at $20^{\circ} \mathrm{C}$ and 0.0415 and $0.0432 \mathrm{~min}^{-1}$ at 12.7 and $13.3^{\circ} \mathrm{C}$ respectively. Day-night comparison of gut contents measured in individual $A$. tonsa, fed $T$. constricta at $8^{\circ} \mathrm{C}$, revealed considerable individual variability. Range in gut contents was about 50 -fold during the day ( 0.17 to $8.97 \mathrm{ng}$ pigment copepod $\left.{ }^{-1}\right)$, and 100 -fold at night ( 0.0 to $13.66 \mathrm{ng}$ copepod $\left.{ }^{-1}\right)$. Distribution of gut content values was skewed towards lower values, especially during daytime. However all but 1 copepod in the day/night sequence had a measurable amount of food in the gut, indicating fairly recent feeding.
\end{abstract}

\section{INTRODUCTION}

Diel feeding rhythms have been widely reported among marine copepods (Fuller 1937, Wimpenny 1938, Mackas \& Bohrer 1976, Daro 1980, 1988, Head et al. 1984, 1985, Batchelder 1986, Harding et al. 1986, and others). Maximum feeding intensity usually occurs at night or at dusk; reports of increased daytime feeding (Boyd et al. 1980, Daro 1985, Kiørboe et al. 1985, Roman et al. 1988) are rare. Although diel feeding rhythms are often associated with diel vertical migrations (Gauld 1953), the 2 behaviors appear to be controlled independently (Stearns \& Forward 1984a, b, Head et al. 1985, Stearns 1986, Dagg et al. 1989). Diel feeding rhythms have been observed in non-migratory species (Hayward 1980) and in non-migrating populations of migratory species (Nicolajsen et al. 1983, Daro 1985, 1988, Hattori 1989). There is evidence that food limitation may altẹr or suppress diel migratory or feeding rhythms (Boyd et al. 1980, Dagg 1985, Dagg \&
Walser 1987, Johnsen \& Jakobsen 1987, Daro 1988, Gliwicz \& Pijanowska 1988). However, well defined diel feeding rhythms have been observed even when food availability is low (Dagg \& Grill 1980, Simard et al. 1985, Runge \& Ingram 1988).

Acartia tonsa is an abundant copepod in estuarine waters of the East and Gulf coasts of North America; adult females generally appear to be food limited (Durbin et al. 1983, Ambler 1985, 1986, Beckman \& Peterson 1986). Although diel feeding rhythms have been observed in this species (Kleppel et al. 1985, 1988, Stearns 1986, Stearns et al. 1987), the relation between diel feeding periodicity and food availability is largely unknown.

In the present study, diel changes in feeding behavior and gut evacuation rate in adult female Acartia tonsa were investigated in relation to food availability. Temperatures ranged from 8 to $20^{\circ} \mathrm{C}$ in the different experiments, and cultured algae as well as natural plankton were used as food. Most gut pigment meas- 
urements were obtained from groups of copepods, but in one experiment gut contents in individual copepods were measured.

\section{MATERIAL AND METHODS}

Experimental apparatus and analytical methods. Plankton: Zooplankton were collected with vertical hauls of a $303 \mu \mathrm{m}$ mesh, $0.5 \mathrm{~m}$ diameter net, at a station in lower Narragansett Bay (Fig. 1). Station depth was about $7 \mathrm{~m}$. The catch was diluted with surface bay water and returned within $1 \mathrm{~h}$ to the laboratory. Thalassiosira weissflogii was used as food in all laboratory experiments except in the study of individual copepod feeding behavior, where, because of the colder temperature, T. constricta was used. Both phytoplankton species are unicellular diatoms. Phytoplankton were cultured in F/2 media (Guillard \& Ryther 1962), under the same temperature and light cycle as used in the feeding experiments. Cells were used while in the log phase of growth.

Experimental apparatus: The first laboratory study of diel feeding behavior, in September 1984, was carried out using 41 widemouth glass jars, mounted on a 1 rpm plankton wheel. The wheel was set inside a water bath to maintain temperature control. Illumination was provided by 'cool-white' fluorescent lights mounted

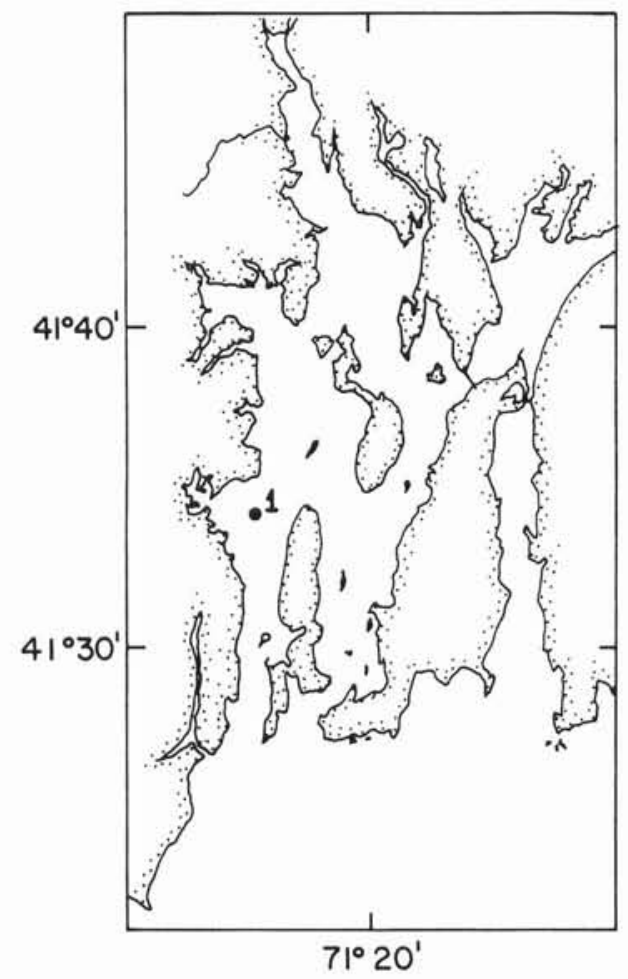

Fig. 1. Station location in Narragansett Bay, Rhode Island, USA overhead; the photon flux density (measured with a Biospherical Instruments QSL-100 irradience meter) was $16 \mu \mathrm{E} \mathrm{m}^{-2} \mathrm{~s}^{-1}$, and a light-dark cycle appropriate to the time of year was used. The second laboratory study of diel feeding behavior and the diel study of gut evacuation rate, in September 1985, were carried out in cylindrical, polyethylene lined fiberglass tanks. Tank dimensions were $71 \mathrm{~cm}$ diameter $\times 109 \mathrm{~cm}$ depth; the capacity was 3801 . Mlumination was provided by Sylvania Metallarc Lamps mounted above each tank. A neutral density filter was used to reduce the light intensity in the tanks; the photon flux density at the water surface was $124 \mu \mathrm{E} \mathrm{m}^{-2} \mathrm{~s}^{-1}$. Each tank was surrounded by a water jacket, through which temperature controlled water was circulated to maintain temperature control. Tanks were mixed with horizontal paddles mounted near the surface, middle and bottom along a central vertical axis, driven by a reversing motor with a $1 \mathrm{~min}$ on, $1 \mathrm{~min}$ off timing cycle. Two diel feeding studies were carried out in October 1984, using one of the $15 \mathrm{~m}^{3}$ mesocosms at the Marine Ecosystem Research Laboratory (MERL), University of Rhode Island Graduate School of Oceanography, USA. These mesocosms ( $2 \mathrm{~m}$ diameter $\times 5 \mathrm{~m}$ depth) provided an opportunity for studying processes on captive but naturally reproducing plankton communities, and should more closely represent in situ feeding conditions than can ordinarily be achieved in the laboratory. The tanks, constructed of fiberglass with a white gelcoat covering, were located outdoors and received natural illumination. Seawater from near the mouth of lower West Passage, Narragansett Bay, was added 4 times daily; the mean water residence time in the tanks was about $30 \mathrm{~d}$, similar to the mean value for Narragansett Bay. The bottoms of the tanks are, as a rule, covered with a $37 \mathrm{~cm}$ thick layer of sediment and associated benthos obtained intact from the bay, but at the time of our experiment in Mesocosm 2 there was no sediment layer present. The tank was mixed with 3 paddles attached horizontally to a PVC pipe which extended down the central axis of the tank. Paddles were located near the surface, middle and bottom of the tank. The central axis was rotated on a schedule of $90 \mathrm{~s}$ clockwise, $90 \mathrm{~s}$ off, $90 \mathrm{~s}$ counterclockwise, $90 \mathrm{~s}$ off. This procedure provided a gentle mixing of the tank and prevented the development of a thermocline on sunny days.

Pigment determinations: In these experiments it was essential that the copepods be collected and handled quickly, but with a minimum of disturbance. Copepod gut evacuation rate was rapid, and it was necessary to anesthetize the copepods to prevent gut evacuation during sorting. Collections of zooplankton from the 3801 experimental tanks and the MERL mesocosms were made with shallow plexiglass cylinders, $5 \mathrm{~cm}$ 
deep and between 19.5 to $24.8 \mathrm{~cm}$ in diameter, with 250 um Nitex screen on the bottom. Different diameter cylinders, which sampled different volumes, were used according to the density of plankton in the tank and the number of copepods needed for each measurement. The cylinders were weighted and lowered to the bottom of the tank, then pulled vertically to the surface using monofilament line, thus providing a representative sample of the population from all depths. Copepods were rinsed with filtered seawater into a 7 $\mathrm{cm}$ diameter plexiglass cylinder, with openings on the sides and bottom covered with $202 \mu \mathrm{m}$ Nitex screen; the chamber was kept continuously submerged to prevent vigorous impingement of the plankton against the screen. The cylinder was then dipped into a solution of $0.576 \mathrm{~g}$ MS222 (3-aminobenzoic acid ethyl ester) $1^{-1}$ of filtered seawater, which immediately anesthetized the copepods and prevented evacuation of gut contents. Copepods were not killed by the anesthetic and would recover if transferred to filtered seawater. Filtered seawater and anesthetic solution were of the same experimental temperature to reduce shock to the copepods. After anesthesia the copepods were rinsed with chilled $\left(4^{\circ} \mathrm{C}\right) \mathrm{MS} 222$ solution into small plastic petri dishes and stored over crushed ice in the dark, until they could be sorted.

Copepods incubated in glass jars were recovered by pouring the jar contents directly into the screen-sided cylinder, anesthetized and processed as just described. About 20 to $30 \mathrm{~s}$ were required to collect and anesthetize the copepods from both tanks and jars. In most of the experiments, copepods were sorted in groups onto Whatman GF/A glass fiber filters, wrapped in aluminum foil and frozen. Sorting was done under subdued light, and the copepods were kept chilled during this process. Frozen samples were processed within $24 \mathrm{~h}$. Pigments were determined by grinding the filters in $90 \%$ aqueous acetone, and reading the samples before and after acidification on a Turner Designs Model 10 fluorometer (Parsons et al. 1984). Pigment values for both phytoplankton and copepod gut contents are reported as the total of chlorophyll a + pheopigments (computed as chlorophyll a equivalents). In the study of individual gut pigments, the copepods were collected and anesthetized as just described, but were then transferred individually to centrifuge tubes. These were filled with $5 \mathrm{ml}$ of $90 \%$ acetone, capped and stored for $17 \mathrm{~h}$ in a freezer to extract the chlorophyll pigments. Samples were then read on the fluorometer and the total gut pigments per copepod determined.

Phytoplankton pigments were determined by filtering subsamples onto Whatman GF/F glass fiber filters, ground in $90 \%$ acetone and analysed as decribed above. Subsamples were also preserved in Lugol's sol- ution, and cell concentrations determined using a Coulter Model ZM particle counter. Five replicate subsamples of $2 \mathrm{ml}$ were counted, and the mean value used. Total chlorophyll $a+$ pheopigment content per cell was then calculated. This value was used to convert the total pigments per copepod to the equivalent number of Thalassiosira weissflogii cells, assuming no degradation of chlorophyll pigments to non-fluorescing compounds.

The concentration of MS222 needed to immobilize the copepods, and the efficacy of the anesthetic to stabilize gut pigments, were determined in a series of preliminary trials. Adult female Acartia tonsa were transferred to 6 concentrations between 0.16 and $5.17 \mathrm{~g}$ MS222 $1^{-1}$ of filtered seawater, placed in a refrigerator and their activity periodically checked during the following $24 \mathrm{~h}$. Concentrations $\leq 0.31 \mathrm{~g} \mathrm{l}^{-1}$ did not sufficiently anesthetize the copepods, which continued to swim actively; $0.62 \mathrm{~g} \mathrm{l}^{-1}$ immobilized but did not kill the copepods, while concentrations $\geq 1.24 \mathrm{~g} \mathrm{l}^{-1}$ caused mortality. After $24 \mathrm{~h}$ copepods exposed to $\leq 0.62 \mathrm{~g} \mathrm{l}^{-1}$ were still alive and resumed swimming when transferred to filtered seawater. The final concentration of $0.576 \mathrm{~g} \mathrm{MS}^{2} 22 \mathrm{1}^{-1}$ was chosen after further trials to determine the lowest effective dose. Adult female $A$. tonsa and $A$. hudsonica were observed in Petri dishes after the addition of anesthetic and did not produce fecal pellets. Gut pigments in A. tonsa fed Thalassiosira weissflogii, then anesthetized and kept chilled and in the dark, were stable for $2 \mathrm{~h}$; gut pigments in anesthetized A. hudsonica females (Wlodarczyk 1988) were stable for $3.3 \mathrm{~h}$, the longest period tested. In the present study, storage of copepods under anesthesia did not exceed $30 \mathrm{~min}$.

Copepods may retain a small amount of residual fluorescence even after having been separated from their food for many hours (Mackas \& Bohrer 1976). Gut fluorescence in Acartia spp. females after several hours in filtered seawater ranged from non-detectable to a small, variable amount. Since gut contents will decline below the sensitivity of our analytical technique, a small positive fluorescence in starved copepods probably represents incomplete evacuation of the last meal, or reingestion of fecal pellets, and is not a true 'background' fluorescence intrinsic to the copepod (see also Baars \& Helling 1985). Therefore no correction for 'background' fluorescence was made.

Carbon and nitrogen determinations: Carbon and nitrogen content were determined on groups of adult female Acartia tonsa. Copepods were anesthetized, briefly rinsed in deionized water, transferred to a small, precombusted aluminum boat and dried in a dessicator. Measurements were made on a HewlettPackard 185B Carbon-Hydrogen-Nitrogen Analyzer. Phytoplankton samples were filtered onto precom- 
busted glass fiber filters for carbon and nitrogen determination.

Laboratory experiments. Evacuation rates: For measurement of the instantaneous gut evacuation rate $\mathrm{R}$, copepods were transferred from their food to filtered seawater and the decline in gut contents monitored over time. Copepods were gently collected in a $25 \mathrm{~cm}$ diameter, 201 capacity plexiglass container with 202 $\mu \mathrm{m}$ screen on the bottom. The container was slowly lifted from the media, dipped into a 201 bucket containing filtered seawater to remove adhering phytoplankton, and transferred to a second bucket of clean filtered seawater. Copepods were then dispensed into replicate beakers and placed into an incubator at the experimental temperature. These steps required about $1 \mathrm{~min}$, after which sampling was begun. At regular intervals, the contents of one of the beakers were gently concentrated on a submerged screen, and the copepods anesthetized and processed as previously described. Three replicate groups of 20 adult female Acartia tonsa were obtained at each sampling time for measurement of gut contents. Instantaneous gut evacuation rate was computed from the slope of the relation between gut contents and time, assuming that gut evacuation is an exponential process. Curves were fit using a non-linear least squares estimation procedure - procedure NLIN, DUD method of computation (Ralston \& Jennrich 1979) - from the Statistical Analysis System (SAS) Version 5, on an IBM 4381 computer.

Laboratory diel feeding, Expt 1 (high food): Plankton were collected on 24 Sep 1984. At the laboratory adult female Acartia tonsa were sorted from the mixed

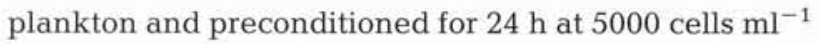
Thalassiosira weissflogii. Temperature was $20^{\circ} \mathrm{C}$ and a $12 \mathrm{~h}$ light : $12 \mathrm{~h}$ dark cycle was used, with the dark period between 18:00 and 06:00 h Eastern Daylight Time (EDT). On the following morning, groups of 20 adult female $A$. tonsa were pipetted into 41 widemouth glass jars containing 2000 cells $\mathrm{ml}^{-1} \mathrm{~T}$. weissflogii in filtered seawater. Three additional 11 jars containing only $T$. weissflogii served as controls for measurement of phytoplankton growth rate during the experiment. Jars were capped and placed on the plankton wheel; after $1.5 \mathrm{~h}$ to permit the copepods to adjust to the new feeding level, sampling was begun. Three replicate jars were retrieved from the wheel at $5 \mathrm{~h}$ intervals, beginning at $13: 15 \mathrm{~h}$ and continuing for $25 \mathrm{~h}$ thereafter, for determination of copepod gut pigment content. A $50 \mathrm{ml}$ subsample was pipetted from each jar for phytoplankton cell counts and pigment determination, and the copepods were collected for measurement of gut pigments. Measurements of copepod carbon and nitrogen content were made on 3 groups of 20 adult female $A$. tonsa at the beginning of the ingestion measurement, after the $24 \mathrm{~h}$ preconditioning.
For measurement of gut evacuation rate $\mathrm{R}$, a subset of the field-collected copepods were fed 5000 cells ml $^{-1}$ of Thalassiosira weissflogii for $24 \mathrm{~h}$. The copepods were then transferred from food to filtered seawater, and measurements of gut pigments were made at $7 \mathrm{~min}$ intervals for $42 \mathrm{~min}$. Each sample comprised 3 groups of 20 adult female Acartia tonsa. A comparison was made between the estimates of total ingestion during the $25 \mathrm{~h}$ experimental period, according to the change in phytoplankton cell numbers, and the diel change in copepod gut pigments. For the first estimate, phytoplankton control jars were sampled at both beginning and end of the experiment, at time $=0$ and $25 \mathrm{~h}$, and the instantaneous growth rate computed. Total ingestion during the experiment was computed from the final 3 grazer jars retrieved at time $=25 \mathrm{~h}$, based on initial and final cell counts in those jars corrected for the phytoplankton growth rate. Equations were those of Frost (1972). Point estimates of feeding rate at $5 \mathrm{~h}$ intervals were made from the measurements of gut contents, corrected for gut evacuation rate, according to the Elliott \& Persson Model I (1978)

$$
\mathrm{C}_{\mathrm{t}}=\mathrm{R} \mathrm{S}_{\mathrm{t}}
$$

This is a short form of the more general equation

$$
C_{t}=\left(S_{t}-S_{0} e^{-R t}\right) R t /\left(1-e^{-R t}\right)
$$

where $\mathrm{C}_{\mathrm{t}}=$ consumption in $\mathrm{t} \min ; \mathrm{S}_{\mathrm{t}}=$ gut content at time $t ; R=$ instantaneous gut evacuation rate $\mathrm{min}^{-1}$.

In Model $\mathrm{I}$ the predator is assumed to feed at a constant rate during time $t_{0}, t_{t}$. Elliott \& Persson (1978) demonstrated that even if this assumption is violated, good estimates of feeding rate can be obtained, provided sampling of gut contents is frequent enough to provide a good description of the diel change in gut contents. Point estimates of feeding rate are plotted vs time, and the area under the resulting curve equals total ingestion during the diel period.

Laboratory diel feeding, Expt 2 (3 food levels): Copepods were collected on 3 September 1985. On return to the laboratory the plankton were split into 3 groups and transferred to the 3801 tanks, in which the nominal concentrations of Thalassiosira weissflogii were 250,550 , and 7000 cells $\mathrm{ml}^{-1}$. Plankton were not presorted, but comprised mainly adult and late stage copepodite Acartia tonsa. Temperature was $20^{\circ} \mathrm{C}$ and a $12.5 \mathrm{~h}$ light : $11.5 \mathrm{~h}$ dark cycle was used, with the dark period between 19:00 and 06:30 h EDT. Copepods were preconditioned for $24 \mathrm{~h}$ at these 3 levels of feeding, and then were sampled for measurement of gut content at $3 \mathrm{~h}$ intervals between $12: 00$ and 12:00 h on 4/5 September. Six replicate groups of 10 adult female A. tonsa were sorted per sample. Phytoplankton samples were collected from each tank at each sampling time for cell counts and cell pigment measurements. 
The phytoplankton were counted immediately since at the 2 lower food concentrations zooplankton grazing caused a slight reduction in phytoplankton concentration. The lower concentrations were below the critical concentration on the ingestion curve, making ingestion rate concentration-dependent. Additions of stock culture were made at intervals to maintain constant experimental conditions. At the highest cell concentration some phytoplankton net growth occurred, where the concentration increased from 6600 to 7600 cells $\mathrm{ml}^{-1}$ during the $24 \mathrm{~h}$ experiment. We did not attempt to correct for the increase in phytoplankton abundance, since this feeding level was well above the critical concentration and such changes in phytoplankton abundance were unlikely to affect ingestion rate. Feeding rate was estimated from the measurements of gut contents, and the mean gut clearance rate from the diel study of evacuation rate, according to Eq. (1). At the end of the experiment an additional 6 replicate groups of 10 female $A$. tonsa were collected from each tank for measurement of carbon and nitrogen content.

Day-night comparison of gut contents in individual copepods (high food): Plankton were collected on the morning of $18 \mathrm{Dec} 1985$. Water temperature was $6.8^{\circ} \mathrm{C}$. Acartia tonsa was near the end of its seasonal cycle, but was still abundant in the adult population. Within $1 \mathrm{~h}$ after collection, 6 groups of 30 adult female $A$. tonsa were sorted into 21 glass jars containing 5000 cells ml $^{-1}$ of Thalassiosira constricta, and transferred to the plankton wheel. A $9.5 \mathrm{~h}$ light: $14.5 \mathrm{~h}$ dark cycle was used, with the dark period from 16:00 to 06:30 h Eastern Standard Time (EST). Temperature was $8.0^{\circ} \mathrm{C}$. Three jars were retrieved at $22: 30 \mathrm{~h}$ on $18 \mathrm{Dec}$, and the final 3 jars at $12: 30 \mathrm{~h}$ on $19 \mathrm{Dec}$, for measurement of individual copepod gut contents. Copepods had thus been fed $T$. constricta for about $12 \mathrm{~h}$ at the time of the nighttime measurement, and $26 \mathrm{~h}$ at the time of the daytime measurement.

Diel study of gut evacuation rate: Zooplankton were collected on 26 Aug 1985. In the laboratory the mixed zooplankton, principally Acartia tonsa adults and latestage copepodites, were transferred to a 3801 tank and

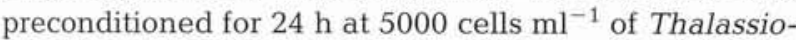
sira weissflogii. Temperature was $20^{\circ} \mathrm{C}$ and the dark period was 19:00 to $06: 30 \mathrm{~h}$ EDT. On the next day, 3 consecutive measurements of gut evacuation rate were made in the daytime $(10: 30,11: 10$, and $11: 45 \mathrm{~h})$ and at night $(21: 15,21: 45$, and $22: 20 \mathrm{~h})$. Copepods used in daytime measurements were thus preconditioned for a lesser time $(24 \mathrm{~h})$ than those used for night-time measurements (35 h). Phytoplankton abundance was monitored and remained near the desired concentration (mean $=4790$ cells $\mathrm{ml}^{-1}$ ). For each measurement of gut clearance rate, plankton were collected from the tank using the plexiglas cylinders, transferred to filtered seawater, and dispensed into 81 beakers placed in a $20^{\circ}$ incubator. Experimental procedures for recovery and processing copepods were as described for the diel feeding studies, except that samples were collected more frequently, at $3 \mathrm{~min}$ intervals for $21 \mathrm{~min}$. Three replicate groups of 20 adult female $A$. tonsa were sorted for each measurement of gut pigments.

Mesocosm diel studies, MERL Diel 1 and 2 (natural food). Two diel studies of in situ feeding were carried out in the MERL mesocosms, on 11 to 12 and 18 to 19 Oct, 1984. In each study the experimental period began at 07:00 $\mathrm{h}$ EDT and concluded at 10:00 h on the following day. Zooplankton were collected at $3 \mathrm{~h}$ intervals gut pigments were determined on 3 replicate groups of 20 adult female Acartia tonsa. Phytoplankton samples were collected at $1 \mathrm{~m}$ depth intervals between 0 and 5 $\mathrm{m}$, and pooled to provide an estimate of total phytoplankton abundance in the integrated water column Samples were prefiltered through a $200 \mu \mathrm{m}$ mesh screen to remove macrozooplankton, and then size fractionated into total and $<10 \mu \mathrm{m}$ size classes, to determine how much of the total plant biomass was in the larger size fraction that is most readily available to adult Acartia (Nival \& Nival 1976, Bartram 1980). Subsamples were filtered in triplicate for chlorophyll, carbon and nitrogen determinations. Tank temperature was determined at each sampling time by means of a YSI Telethermometer equipped with a rapid response time thermistor probe. Light intensities were measured by a Licor Model LI190S quantum sensor located above the MERL mesocosms. At the end of each diel experiment, additional zooplankton were collected for measurement of gut evacuation rate. Plankton were transferred to filtered seawater and put into an incubator at the same temperature as the tank. Evacuation rate was measured as described before, except that 3 replicate groups of 20 adult female $A$. tonsa females were sorted for gut pigment analysis at $5 \mathrm{~min}$ intervals over a 30 min period. The slightly longer experimental duration and interval between samples were used because of the lower temperature in the mesocosm experiments and the correspondingly lower gut clearance rate. An additional 4 groups of 20 female $A$. tonsa were sorted into precombusted aluminum boats for carbon and nitrogen analysis.

\section{RESULTS}

\section{Laboratory studies}

\section{Laboratory diel feeding, Expt 1 (high food)}

During the evacuation experiment gut contents declined curvilinearly, and very rapidly, with about $70 \%$ of gut contents being evacuated during the first 
14 min (Fig. 2D). Thereafter, gut contents declined more slowly, probably because the gut was no longer being stimulated by the ingestion of food. Since our purpose was to estimate as nearly as possible the evacuation rate in feeding copepods, data from the later period of evacuation, where gut contents had declined below $30 \%$ of the initial value, were not used for the estimation of $\mathrm{R}$. The value of $\mathrm{R}$ estimated from the data from 0 to $14 \mathrm{~min}$ was $0.0907 \mathrm{~min}^{-1}$ (Table 1). The corresponding mean gut residence time $(=1 / \mathrm{R})$ was $11.0 \mathrm{~min}$.

During the diel feeding experiment the mean \pm SE concentration of Thalassiosira weissflogii was $1990 \pm 20$ cells $\mathrm{ml}^{-1}$ (Table 1), corresponding to $219 \mu \mathrm{g}$ carbon and $39.6 \mu \mathrm{g}$ nitrogen $1^{-1}$. Acartia tonsa females exhibited a diel feeding rhythm, with maximum gut content at night $(6.97 \mathrm{ng}$ total pigments $=1040$ cells $T$. weissflogii copepod ${ }^{-1}$; Fig. 2A, B, Table 2). The amplitude of the diel rhythm, as measured by the ratio of the maximum : minimum gut contents, was 3.1 (Table 2). Corresponding maximum and minimum feeding rates were 94.3 and 30.8 cells copepod ${ }^{-1} \min ^{-1}$ (Table 2, Fig. 2B); total daily ingestion of cells, estimated by integration of the curve in Fig. 2B, was 90650 cells copepod $^{-1} \mathrm{~d}^{-1}$, or $9.97 \mu \mathrm{g}$ carbon, $1.80 \mu \mathrm{g}$ nitrogen $\mathrm{d}^{-1}$ (Table 3). Mean copepod body carbon and nitrogen were 6.72 and $1.73 \mu \mathrm{g} \operatorname{copepod}^{-1}$, respectively (Table 1); feeding rates were thus equivalent to $148 \%$ body carbon and $104 \%$ body nitrogen $\mathrm{d}^{-1}$ (Table 3 ). Clearance rates over the diel period ranged between 17.0 and $54.7 \mu \mathrm{l} \mathrm{copepod}{ }^{-1} \mathrm{~min}^{-1}$ (Fig. 2C, Table 2), for a total of $51.6 \mathrm{ml}$ copepod ${ }^{-1} \mathrm{~d}^{-1}$ (Table 3).

Table 1. Food abundance, temperature, instantaneous gut evacuation rate $\left(\mathrm{R} \mathrm{min}{ }^{-1}\right)$, and Acartia tonsa carbon and nitrogen content in the laboratory and mesocosm studies of diel feeding behavior in adult females

\begin{tabular}{|c|c|c|c|c|c|c|c|}
\hline \multirow[t]{2}{*}{ Expt } & \multicolumn{3}{|c|}{ Mean food abundance } & \multirow{2}{*}{$\begin{array}{c}\text { Temp } \\
\left({ }^{\circ} \mathrm{C}\right)\end{array}$} & \multirow{2}{*}{$\begin{array}{c}\mathrm{R} \\
\left(\min ^{-1}\right)\end{array}$} & \multicolumn{2}{|c|}{ Acartia tonsa } \\
\hline & $\begin{array}{c}\text { Total chl } \\
\text { pigments } \\
\left(\mu \mathrm{g}^{-1}\right)\end{array}$ & $\begin{array}{l}\text { Thalassios } \\
\text { Conc. cells } \\
\left(\mathrm{ml}^{-1}\right)\end{array}$ & $\begin{array}{l}\text { weissflogii } \\
\text { Pigments } \\
\left(\mathrm{pg} \text { cell }^{-1}\right)\end{array}$ & & & $\begin{array}{c}\mathrm{C} \\
(\mu \mathrm{g})\end{array}$ & $\begin{array}{c}\mathrm{N} \\
(\mu \mathrm{g})\end{array}$ \\
\hline Lab Diel 1 & 13.31 & 1990 & 6.69 & 20 & 0.0907 & 6.72 & 1.73 \\
\hline Lab Diel 2 & $\begin{array}{r}21.65 \\
1.46 \\
0.73\end{array}$ & $\begin{array}{r}7390 \\
570 \\
250\end{array}$ & $\begin{array}{l}2.94 \\
2.59 \\
2.92\end{array}$ & 20 & 0.0894 & $\begin{array}{l}4.78 \\
4.50 \\
3.71\end{array}$ & $\begin{array}{l}1.18 \\
1.16 \\
0.93\end{array}$ \\
\hline MERL Diel 1 & 6.94 & $\begin{array}{l}- \\
-\end{array}$ & $\begin{array}{l}- \\
-\end{array}$ & 13.3 & 0.0415 & 4.71 & 1.32 \\
\hline MERL Diel 2 & 4.56 & - & - & 12.7 & 0.0432 & 5.33 & 1.48 \\
\hline
\end{tabular}
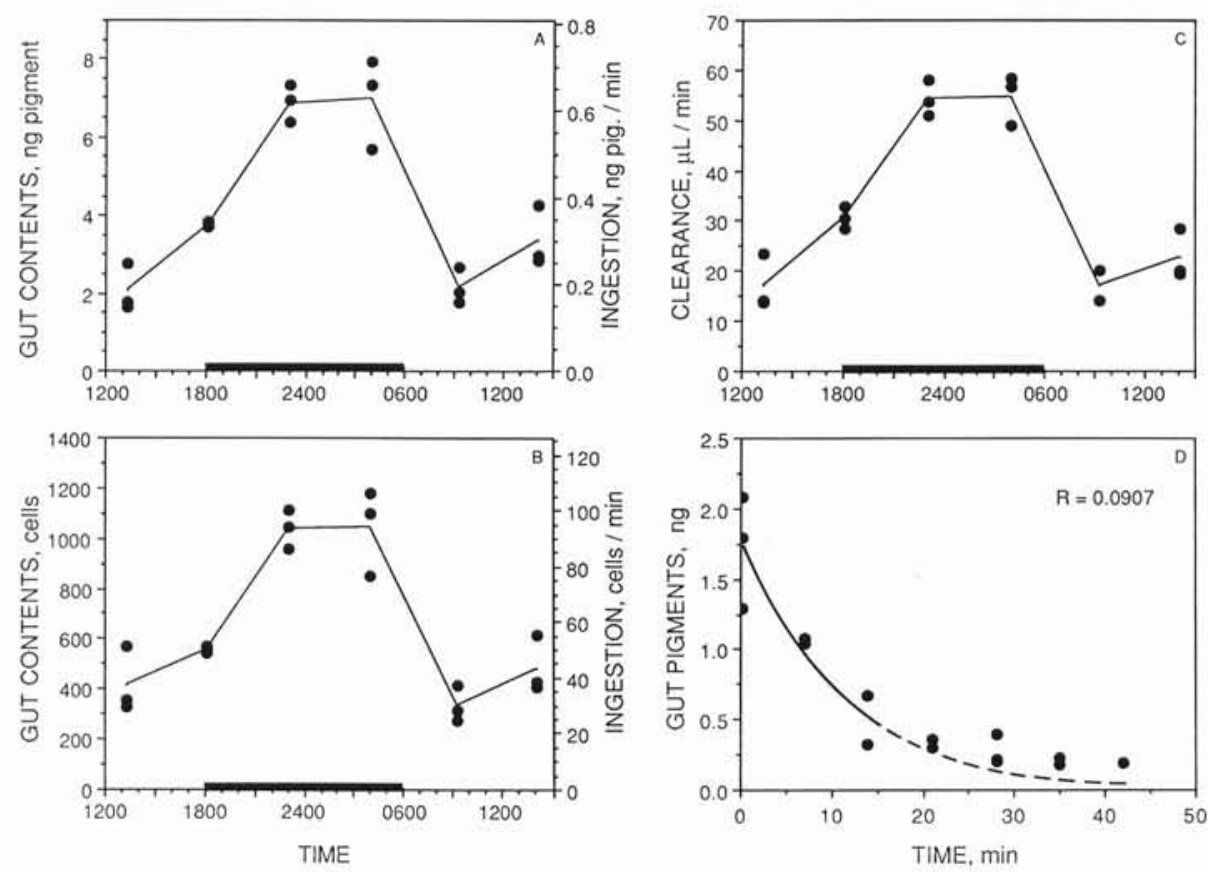

Fig. 2. Acartia tonsa. Laboratory diel feeding, Expt 1 (high food). Copepods fed Thalassiosira weissflogii at $20^{\circ} \mathrm{C}$. (A) Diel changes in gut contents (ng total chlorophyll pigments copepod $^{-1}$ ) and ingestion rate (ng total pigments copepod ${ }^{-1}$ $\min ^{-1}$ ). (B) Same as (A) but for phytoplankton cells. (C) Clearance rates $\left(\mu \mathrm{l}\right.$ copepod $^{-1}$ $\min ^{-1}$ ). (D) Gut evacuation 


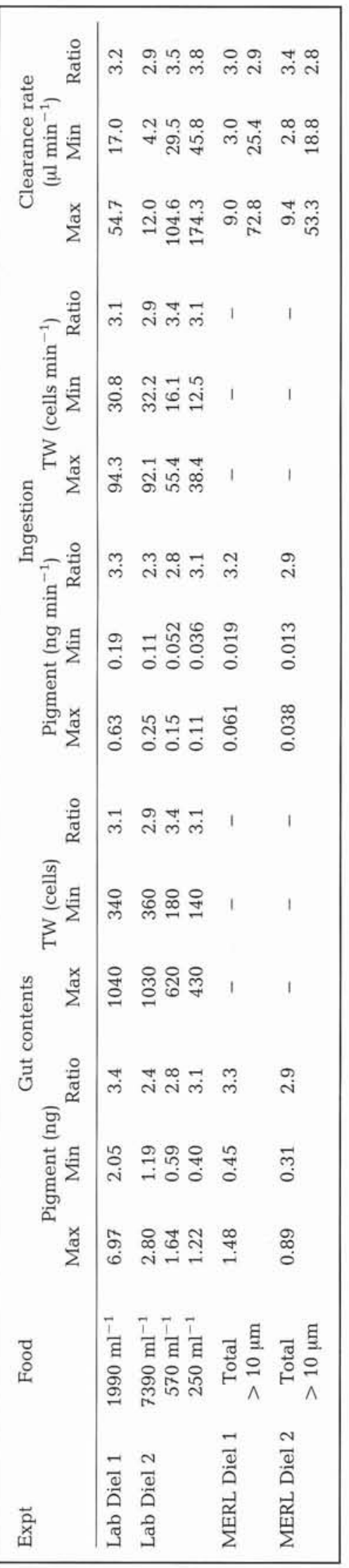

Total ingestion over the $25 \mathrm{~h}$ experimental period, as estimated from the gut pigment method by integration of the area under the curve in Fig. 2B, was 92750 cells per copepod. The corresponding estimates from cell counts, from the 3 replicate jars sampled at the end of the experiment, were 93380,95210 , and 114630 cells $\left(\right.$ mean $=101070$ cells copepod $\left.^{-1}\right)$. Phytoplankton instantaneous growth rate during this period was $0.1465 \mathrm{~d}^{-1}$. The difference between the 2 ingestion estimates was $8.2 \%$.

\section{Diel study of gut evacuation rate}

As in the previous experiment, gut contents declined rapidly, with about $70 \%$ evacuated during the first $12 \mathrm{~min}$ (Fig. 3). Evacuation rates were calculated as before from data obtained during this period. There were no significant differences $(p<0.05)$ between the evacuation rates measured during day and night, where mean values were 0.0903 and $0.0885 \mathrm{~min}^{-1}$, respectively (Table 4). The grand mean of the 6 measurements was $0.0894 \mathrm{~min}^{-1}$, or a mean gut residence time of $11.2 \mathrm{~min}$. This value was close to that obtained during the evacuation measurement made under similar food and temperature conditions in the first laboratory diel study.

The mean gut content at the beginning of the gut evacuation measurements provided an estimate of feeding rate prior to the experiments (Table 4). Gut contents were higher at night-time (mean $=2.62 \mathrm{ng}$ total pigments copepod ${ }^{-1}$ ) than during the day (mean $=1.48 \mathrm{ng}$ pigments copepod ${ }^{-1}$ ), confirming that feeding rate was higher at night. However we cannot determine the full amplitude of the day/night feeding curve since the entire diel period was not covered.

\section{Laboratory diel feeding, Expt 2 (3 food levels)}

Mean \pm SE concentrations of Thalassiosira weissflogii at the different feeding levels were $250 \pm 10$, $570 \pm 50$, and $7390 \pm 130$ cells $\mathrm{ml}^{-1}$, respectively. Phytoplankton abundance increased at the highest food concentration (Fig. 4A), but remained nearly constant at the lower 2 concentrations during the experiment (Fig. 4B). Mean pigment per cell fluctuated somewhat but there was no apparent pattern (Fig. 4C); mean values are presented in Table 1.

There was a pronounced diel rhythm in Acartia tonsa gut contents and ingestion rate in all 3 treatments, which represented severely limiting, moderately limiting, and non-limiting feeding conditions (Fig. 5A, B). Maximum values occurred at night. Maximum gut pigment content in the low, middle, and high food treat- 
Table 3. Acartia tonsa. Diel feeding behavior of adult females fed Thalassiosira weissflogii in laboratory experiments, and natural plankton (total and $10 \mu \mathrm{m}$ ) in mesocosm experiments presented in Tables 1 and 2. Total daily ingestion and clearance rates over the diel cycle, obtained by integration under the curves in Figs. 2, 5, 9, and 10

\begin{tabular}{|lcccccccc|}
\hline Experiment & Food & $\begin{array}{c}\text { Pigment } \\
\left(\mathrm{ng} \mathrm{d}^{-1}\right)\end{array}$ & $\begin{array}{c}\mathrm{TW} \\
\left(\mathrm{cells} \mathrm{d}^{-1}\right)\end{array}$ & $\begin{array}{c}\mathrm{C} \\
\left(\mu \mathrm{g} \mathrm{d}^{-1}\right)\end{array}$ & $\begin{array}{c}\mathrm{N} \\
\left(\mu \mathrm{g} \mathrm{d}^{-1}\right)\end{array}$ & $\begin{array}{c}\% \text { Body C } \\
\left(\mathrm{d}^{-1}\right)\end{array}$ & $\begin{array}{c}\text { \% Body N } \\
\left(\mathrm{d}^{-1}\right)\end{array}$ & $\begin{array}{c}\text { Clearance } \\
\left(\mathrm{ml} \mathrm{d}^{-1}\right)\end{array}$ \\
\hline Lab Diel 1 & $1990 \mathrm{ml}^{-1}$ & 594.6 & 90650 & 9.97 & 1.80 & 148 & 104 & 51.6 \\
Lab Diel 2 & $7390 \mathrm{ml}^{-1}$ & 253.5 & 89100 & - & - & - & - & 11.9 \\
& $570 \mathrm{ml}^{-1}$ & 140.7 & 55210 & - & - & - & - & 99.5 \\
MERL Diel 1 & $\begin{array}{c}250 \mathrm{ml}^{-1} \\
\text { Total }\end{array}$ & 101.3 & 33980 & - & - & - & - & 71.5 \\
& $>10 \mu \mathrm{m}$ & 56.8 & - & 3.47 & 0.53 & 74 & 40 & 8.2 \\
MERL Diel 2 & $\begin{array}{c}\text { Total } \\
>10 \mu \mathrm{m}\end{array}$ & 35.0 & - & 4.52 & 0.67 & 85 & 45 & 7.9 \\
& & & & & & & 53.3 \\
\hline
\end{tabular}

ments were $1.22,1.64$, and $2.80 \mu \mathrm{g}_{\text {copepod }}{ }^{-1}$ respectively, corresponding to 430,620 , and 1030 cells of Thalassiosira weissflogii per copepod (Table 2). These maxima were approximately 3 -fold higher than minima observed during daytime. Maximum ingestion rates were $38.4,55.4$, and 92.1 cells copepod ${ }^{-1} \mathrm{~min}^{-1}$ at the 3 food levels (Figs. 5A, B, Table 2), corresponding to clearance rates of $174.3,104.6$, and $12.0 \mu \mathrm{l} \mathrm{min} \mathrm{m}^{-1}$ (Fig. 6A, Table 2).

Copepod body carbon and nitrogen content at the end of the experiment were similar at 570 and 7390
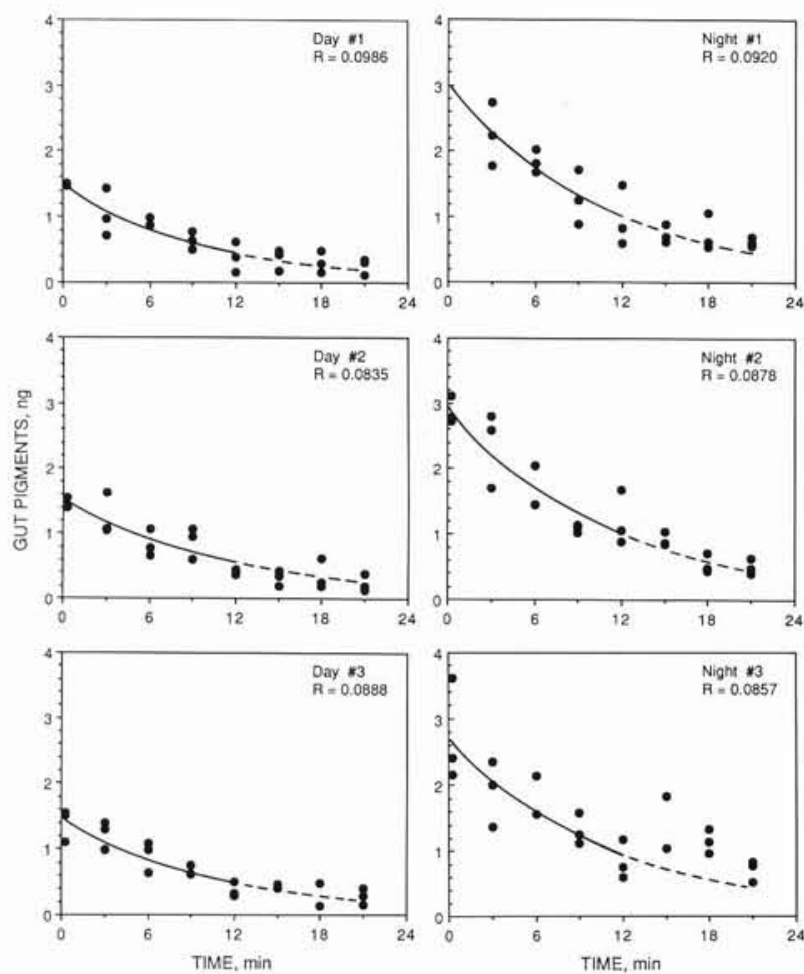

Fig. 3. Acartia tonsa. Comparison of daytime and night-time gut evacuation rates in copepods fed Thalassiosira weissflogii at $20^{\circ} \mathrm{C}$ cells $\mathrm{ml}^{-1}$, but about $20 \%$ lower at 250 cells $\mathrm{ml}^{-1}$ (Table 1). Thus while copepods at 570 cells ml $^{-1}$ were food limited, as indicated by lower ingestion rate than at 7390 cells ml $\mathrm{ml}^{-1}$, they were able to maintain a stable body weight. However copepods at the lowest food concentration lost weight, indicating they were consuming body reserves to meet basic energy requirements.

At all 3 feeding levels, maximum observed gut contents and feeding rates at night were about 3 -fold higher than daytime minima (Table 2), suggesting that the amplitude of the diel feeding cycle was the same. To facilitate comparison of diel curves, ingestion rates were normalized to the maximum observed value at each food concentration (given in Table 2) and expressed as a percentage of that maximum value. The curves are plotted together in Fig. 7A, which reveals a striking regularity in diel feeding pattern at the different levels

Table 4. Acartia tonsa. Comparison of day and night gut evacuation rates of adult females at $20^{\circ} \mathrm{C}$. Gut content at time $\mathrm{t}_{0}$ is the intercept, instantaneous gut evacuation rate $\left(\mathrm{R} \mathrm{min}{ }^{-1}\right)$ is the slope of the exponential curve fitted to the gut evacuation data in Fig. 3

\begin{tabular}{|lcc|}
\hline Time & $\begin{array}{c}\text { Gut content at time } t_{0} \\
\overline{\mathrm{x}} \pm \mathrm{SE} \text { total pigment } \\
(\mathrm{ng} \text { copepod }\end{array}$ & $\begin{array}{c}\text { Instantaneous gut } \\
\text { evacuation rate } \\
\left(\mathrm{R} \mathrm{min}^{-1} \pm \mathrm{SE}\right)\end{array}$ \\
\hline Day & $1.48 \pm 0.13$ & $0.0986 \pm 0.0177$ \\
& $1.49 \pm 0.11$ & $0.0835 \pm 0.0151$ \\
& $1.46 \pm 0.10$ & $0.0888 \pm 0.0148$ \\
Night & $\overline{\mathrm{x}}=1.48$ & $\overline{\mathrm{x}}=0.0903$ \\
& $3.03 \pm 0.41$ & $0.0920 \pm 0.0214$ \\
& $2.90 \pm 0.19$ & $0.0878 \pm 0.0133$ \\
& $2.70 \pm 0.23$ & $0.0857 \pm 0.0179$ \\
& $\overline{\mathrm{x}}=2.62$ & $\overline{\mathrm{x}}=0.0885$ \\
& & \\
& & \\
& &
\end{tabular}



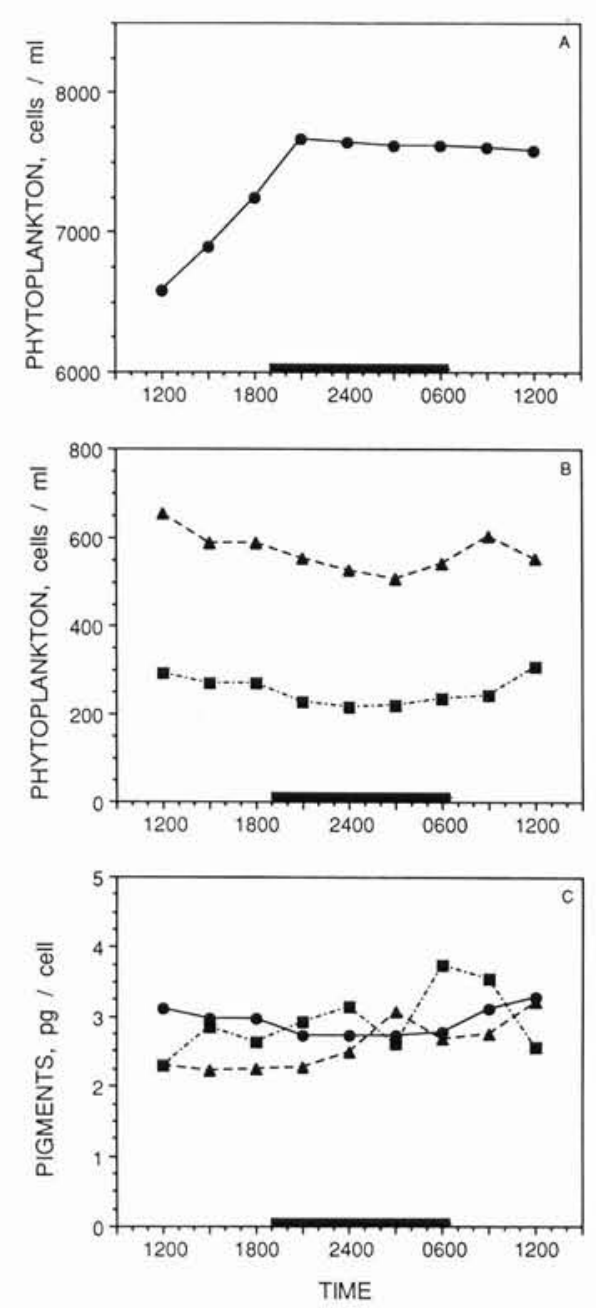

Fig. 4. Acartia tonsa, Laboratory diel feeding, Expt 2 (3 food levels). Copepods fed Thalassiosira weissflogii at $20^{\circ} \mathrm{C}$. Diel changes in cell concentration at (A) the highest and (B) the 2 lower food concentrations. (C) Diel change in pigment per cell

of food. Similarly, percentage changes in clearance rates were extraordinarily close at the 3 food concentrations (Fig. 6B). Thus while the actual ingestion rates differed at the 3 food levels, over the diel cycle copepods changed their voluntary feeding rate by the same proportional amount in all 3 cases. At the lowest food level of 250 cells ml $^{-1}$ copepods retained their diel feeding rhythm, even through they were severely food limited and forced to catabolize bodily carbon and nitrogen.

Overall, the ingestion rate at 570 and 250 cells ml$^{-1}$ averaged about 62 and $38 \%$ respectively of that at 7390 cells $\mathrm{ml}^{-1}$ (Table 3 ), with no significant diel trend in the relationship (Fig. 7B: the constant relationship is a direct consequence of the similarity of the curves in Fig. 7A).
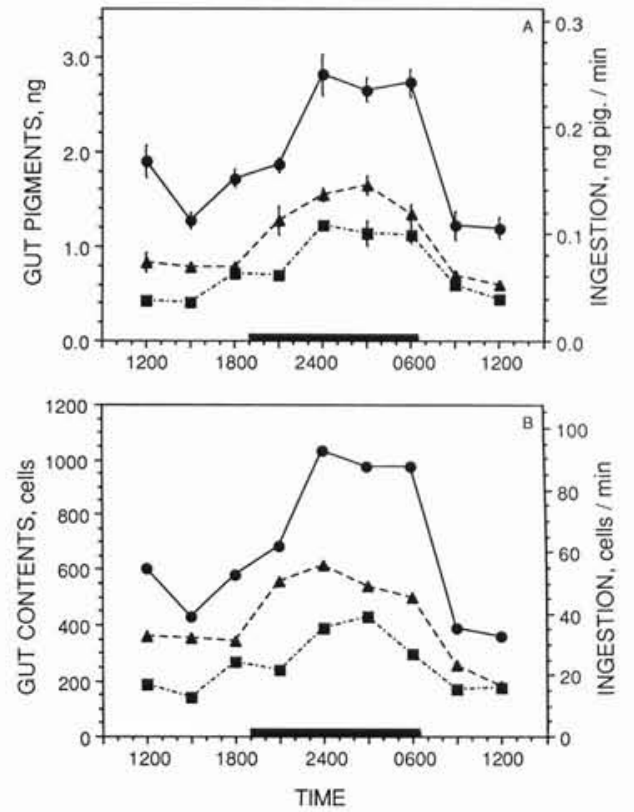

Fig. 5. Acartia tonsa. Laboratory diel feeding, Expt 2 (3 food levels). Copepods fed Thalassiosira weissflogii at $20^{\circ} \mathrm{C}$. Diel changes in gut contents per copepod and ingestion rate copepod ${ }^{-1} \min ^{-1}$ for (A) total chlorophyll pigments and (B) phytoplankton cells
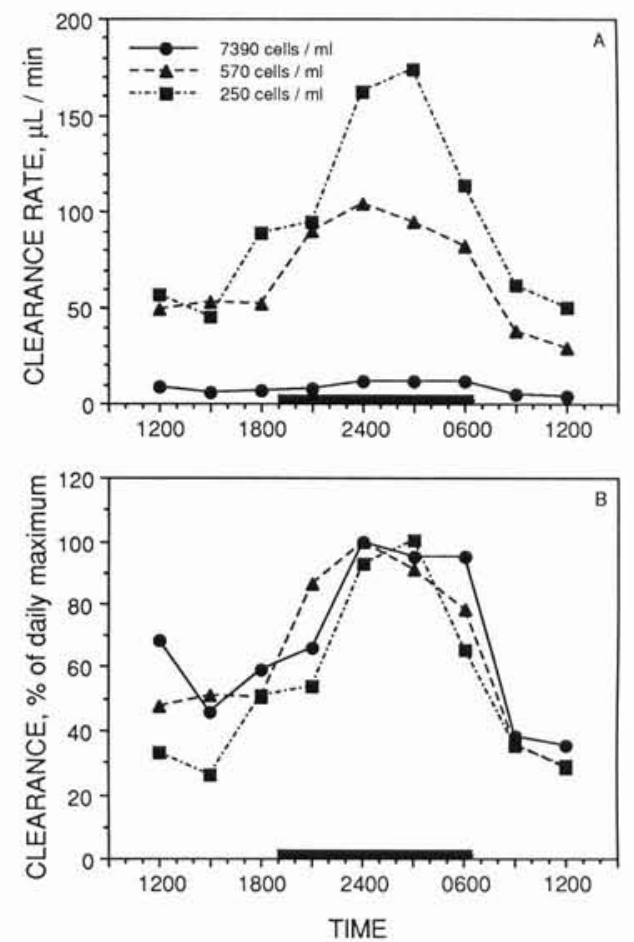

Fig. 6. Acartia tonsa. Laboratory diel feeding, Expt 2 (3 food levels). Copepods fed Thalassiosira weissflogii at $20^{\circ} \mathrm{C}$. (A) Diel changes in clearance rate $\left(\mu l\right.$ copepod $\left.^{-1} \min ^{-1}\right)$. (B) Clearance rate at the 3 food concentrations, normalized to the maximum observed clearance rate at each food level 

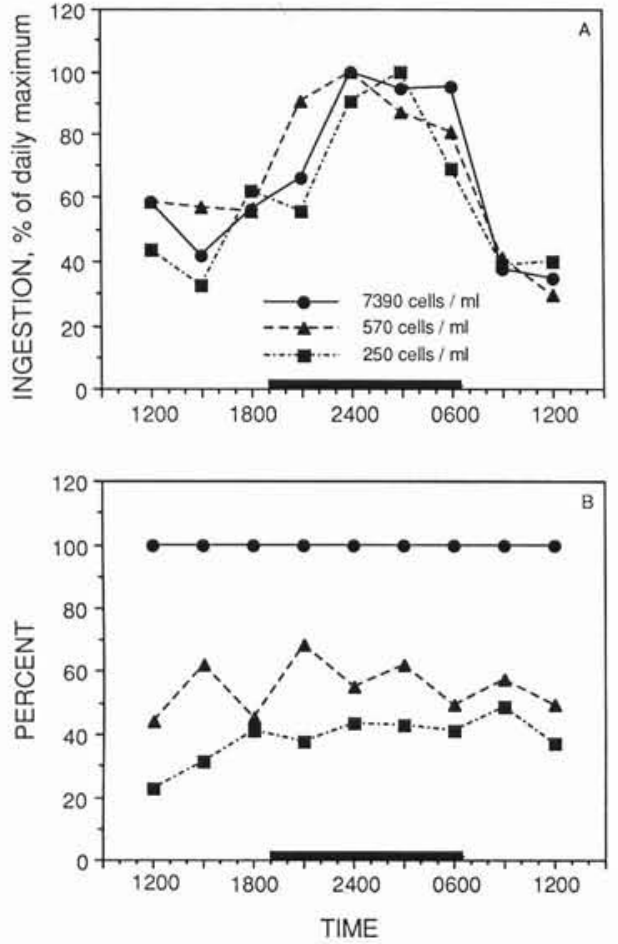

Fig. 7. Acartia tonsa. Laboratory diel feeding, Expt 2 (3 food levels). Copepods fed Thalassiosira weissflogii at $20^{\circ} \mathrm{C}$. (A) Ingestion rate, as a percentage of the maximum rate at each food level during the diel cycle. (B) Ingestion rate, as a percentage of that in the highest food concentration at each sampling time

Day-night comparison of individual gut contents (high food)

There was considerable variability in feeding behavior during both day and night (Fig. 8). Individual values varied about 50 -fold during the day and 100 fold at night (Table 5). The distribution of gut contents departed significantly from normality, being skewed towards lower values. Median and geometric mean gut contents were therefore lower than arithmetic means, which were influenced by a small number of high values (Fig. 8, Table 5). Daytime observations were strongly skewed towards low values, with a modal class of 24 observations ( $=27 \%$ of the total) in the 1.0 to $1.49 \mathrm{ng}$ class. Nighttime data were somewhat more evenly distributed, with a modal class of 10 observations (= $11 \%$ of total observations) in the 2.0 to $2.49 \mathrm{ng}$ class. Maximum value during nighttime (13.66 ng) was considerably higher than during the day (8.97 $\mathrm{ng}$ ).

Mean \pm SE of all daytime values combined, where $\mathrm{n}=90$ copepods, was $2.55 \pm 0.19 \mathrm{ng}$ pigment cope$\operatorname{pod}^{-1}$, with the geometric mean $2.01 \mathrm{ng}$ and median $1.99 \mathrm{ng}$, and the total range 0.17 to $8.97 \mathrm{ng}$ (Table 5).
Nighttime values were significantly higher: arithmetic mean $=3.71 \pm 0.32 \mathrm{ng}$ copepod $^{-1}$, geometric mean $2.65 \mathrm{ng}$, median $3.16 \mathrm{ng}$, and range 0 to $13.66 \mathrm{ng}(\mathrm{n}=$ 88). The coefficient of variation was $68.7 \%$ for daytime measurements, and slightly higher at $79.9 \%$ for the nighttime.

As usual in such non-normal distributions, pooling the individual data into groups reduced the variability of the measurements; we would expect that a large number of such pooled measurements of gut contents would approximate a normal distribution even though the underlying distribution of individual data points was non-normal (Sokal \& Rohlf 1969). The arithmetic mean gut content based on the 3 replicate measurements of 30 copepods was $2.55 \mathrm{ng}$ copepod $^{-1}$, with a range of 2.33 to 2.70 (Table 5). The corresponding value for the nighttime was $3.71 \mathrm{ng}$, with a range of 3.27 to 4.45 .

Nighttime mean and median gut contents were 1.5and 1.6-fold greater than the corresponding daytime values, but this may not reflect the full diel amplitude in feeding since the complete diel cycle was not followed.

With the exception of 1 copepod from the nighttime sample, all individuals in our day-night comparison
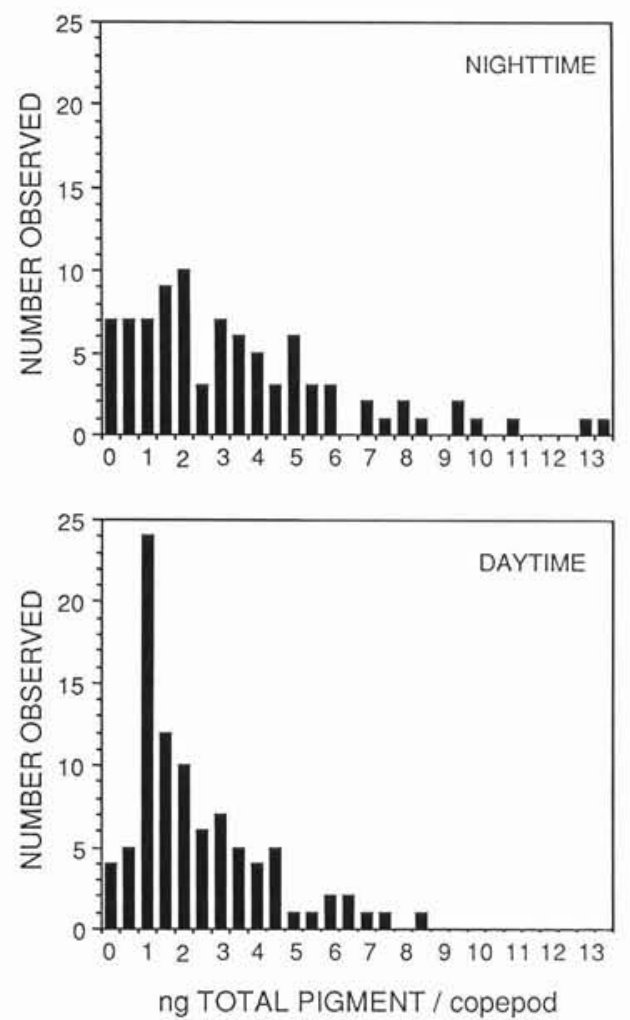

Fig. 8. Acartia tonsa. Comparison of daytime and nighttime gut contents (ng total chlorophyll pigments copepod ${ }^{-1}$ ) in individuals fed Thalassiosira constricta at $8^{\circ} \mathrm{C}$ 
Table 5. Acartia tonsa. Day and night comparison of gut contents of individual adult females fed Thalassiosira constricta at $8{ }^{\circ} \mathrm{C}$

\begin{tabular}{|c|c|c|c|c|c|}
\hline \multirow[t]{2}{*}{ Sample } & \multirow[t]{2}{*}{ No. copepods } & \multicolumn{4}{|c|}{ Gut pigments (ng copepod ${ }^{-1}$ ) } \\
\hline & & $\begin{array}{l}\text { Arithmetic } \\
\text { mean } \pm \mathrm{SE}\end{array}$ & $\begin{array}{c}\text { Geometric } \\
\text { mean } \pm \mathrm{SE}\end{array}$ & Median & Range \\
\hline \multicolumn{6}{|l|}{ Daytime } \\
\hline D1 & 30 & $2.70 \pm 0.41$ & $1.87 \pm 0.48$ & 2.07 & $0.17-8.97$ \\
\hline D2 & 30 & $2.33 \pm 0.23$ & $2.02 \pm 0.33$ & 2.04 & $0.28-6.19$ \\
\hline D3 & 30 & $2.62 \pm 0.31$ & $2.15 \pm 0.35$ & 1.86 & $0.81-6.59$ \\
\hline All & 90 & $2.55 \pm 0.19$ & $2.01 \pm 0.22$ & 1.99 & $0.17-8.97$ \\
\hline \multicolumn{6}{|l|}{ Nighttime } \\
\hline N1 & 30 & $4.45 \pm 0.58$ & $3.62 \pm 0.38$ & 3.52 & $0.00-11.17$ \\
\hline N2 & 30 & $3.27 \pm 0.59$ & $2.08 \pm 0.54$ & 2.47 & $0.12-13.66$ \\
\hline N3 & 28 & $3.40 \pm 0.45$ & $2.49 \pm 0.46$ & 2.71 & $0.37-8.34$ \\
\hline All & 88 & $3.71 \pm 0.32$ & $2.65 \pm 0.27$ & 3.16 & $0.00-13.66$ \\
\hline
\end{tabular}

had measurable amounts of food in the gut, indicating fairly recent feeding. Most copepods maintained a feeding level to keep gut contents $\geq 1 \mathrm{ng}$ pigments during the day and $\geq 2$ ng pigments at night. Since Acartia spp. appears to be an intermittent feeder (Rosenberg 1980, Paffenhöfer \& Stearns 1988), the higher gut content at night implies that the copepods either increased their clearance rate, or extended the duration of each feeding bout, in order to fill the gut to a higher average level.

Because of the need to process the copepods quickly we did not measure body length at the end of the experiment. As a result we cannot determine how much of the observed variability in gut contents was attributable to differences in body size, as opposed to variation in individual feeding rate. However we would expect that the range in gut contents exhibited by an individual copepod is probably smaller than the range to be found within the overall population, which contains individuals of different body size and gut capacity.

\section{Mesocosm diel studies (natural food)}

\section{MERL Diel 1}

In the first mesocosm experiment on 11 to 12 Oct 1984 , both days were bright and sunny. Sunset was at 18:11 $\mathrm{h}$ EDT and sunrise at 06:53 $\mathrm{h}$; maximum photon flux density (4.59 $\mathrm{E} \mathrm{m}^{-2} \mathrm{~h}^{-1}$ ) occurred at 13:00 h (Fig. 9B). Mean temperature was $13.3^{\circ} \mathrm{C}$. Phytoplankton biomass as measured by chlorophyll a showed no significant trends over the diel cycle (Fig. 9C). Mean $\pm \mathrm{SE}$ total pigments were $6.94 \pm 0.10 \mu \mathrm{g} 1^{-1}$, where chlorophyll $a$ and phaeopigments were $4.96 \pm 0.08$ and $1.98 \pm 0.04 \mu \mathrm{g}^{-1}$. Small flagellates were dominant, and most of the phytoplankton biomass occurred in the $<10$ $\mu \mathrm{m}$ size class $(88.9,79.3$, and $86.2 \%$ of total pigments, chlorophyll $a$, and phaeopigments, respectively). Mean carbon:total pigment and nitrogen:total pigment ratios were 61.1 and 9.35. These values were used to convert estimates of copepod ingestion from total pigments to carbon and nitrogen.

Instantaneous gut evacuation rate $\mathrm{R}$ was 0.0415 $\min ^{-1}$, based on data from 0 to $25 \mathrm{~min}$, during which about $70 \%$ of the gut contents were evacuated (Fig. 10C, Table 1). This value, lower than that from the laboratory experiments at $20^{\circ} \mathrm{C}$, reflected the lower temperature in the mesocosms. The mean gut residence time corresponding to this evacuation rate was $24.1 \mathrm{~min}$.

Again there was a pronounced diel periodicity in gut contents, with maximum value at night (1.48 ng total pigments copepod ${ }^{-1}$ : Fig. 9E, G, Table 2). Corresponding maximum ingestion rate was $0.061 \mathrm{ng}$ total pigment copepod $^{-1} \mathrm{~min}^{-1}$, or $3.73 \mathrm{ng}$ carbon and $0.57 \mathrm{ng}$ nitrogen $\min ^{-1}$. The amplitude of the diel feeding curve (3.2) was similar to that observed in the laboratory experiments at $20^{\circ} \mathrm{C}$ (Table 2).

Total daily ingestion rate was $56.8 \mathrm{ng}$ pigment copepod $^{-1}$, or $3.47 \mu \mathrm{g}$ carbon and $0.53 \mu \mathrm{g}$ nitrogen $=$ $74 \%$ body carbon and $40 \%$ body nitrogen copepod ${ }^{-1}$ $\mathrm{d}^{-1}$, where mean copepod body carbon and nitrogen were 4.71 and $1.32 \mu \mathrm{g}$ (Table 3 ). These feeding rates were direct estimates, based upon gut contents. However, computation of clearance rates was less straightforward because so much of the phytoplankton biomass was in the small $<10 \mu \mathrm{m}$ size class, and of unknown availability to the adult female copepods. Minimal and maximal estimates of clearance rate were obtained by relating ingestion rate to total phytoplankton biomass, and the $>10 \mu \mathrm{m}$ biomass (Fig. 10A). Maximum daily clearance rates thus calculated were 9.0 and $72.8 \mu \mathrm{l} \mathrm{copepod}{ }^{-1} \min ^{-1}$ for total and $>10 \mu \mathrm{m}$ total pigments, with the diel feeding amplitude about 3 , 
similar to gut pigments and feeding rate (Table 2). Corresponding daily clearance rates were 8.2 and $60.1 \mathrm{ml} \mathrm{copepod}^{-1}$ (Table 3), with the true value prob-
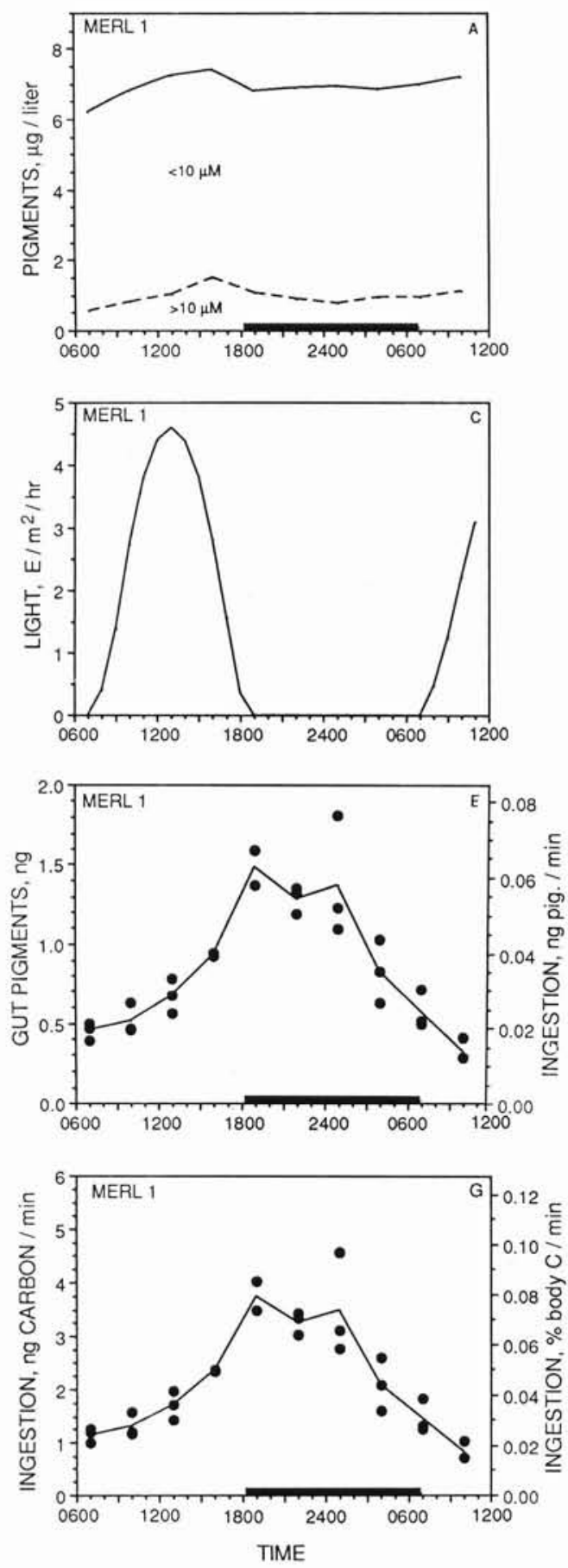

ably somewhere in between, depending upon how much of the $<10 \mu \mathrm{m}$ phytoplankton the copepods actually could capture.
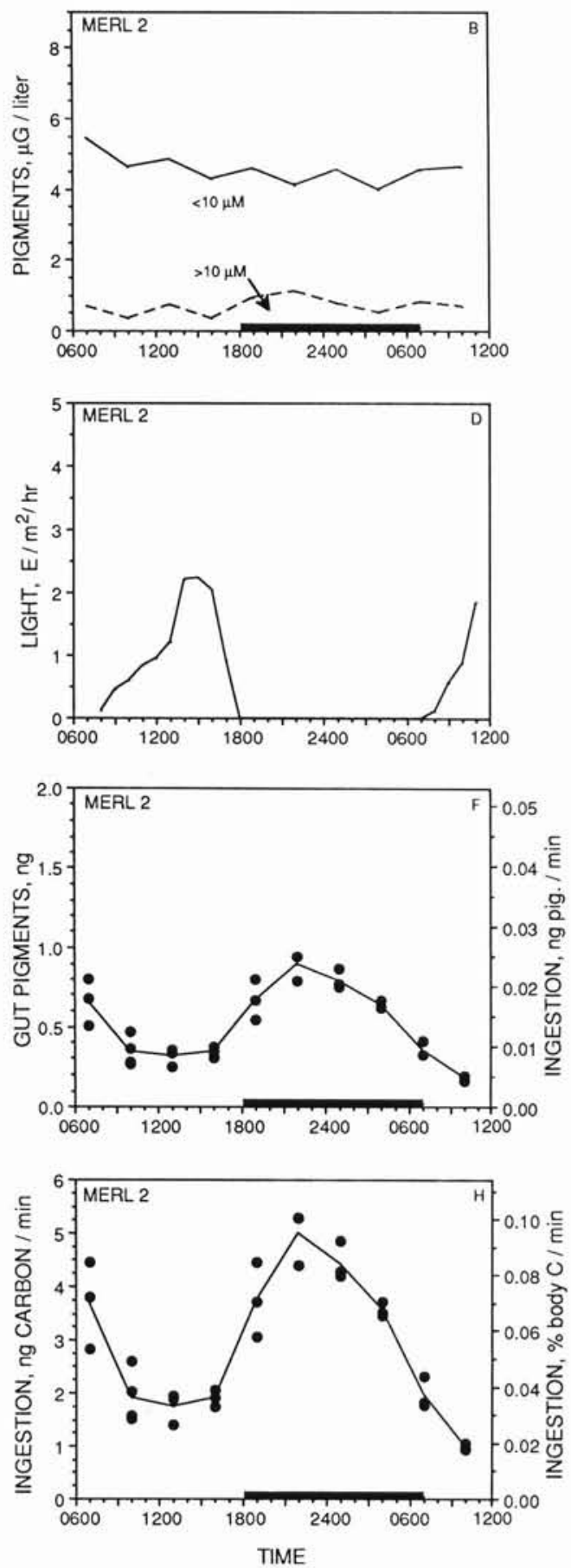

Fig. 9. Acartia tonsa. Mesocosm diel studies, MERL Diel 1 and 2. Copepods fed natural plankton at 12.7 and $13.3^{\circ} \mathrm{C}$. (A, B) Diel changes in total, $>10$ and $<10 \mu \mathrm{m}$ phytoplankton pigments. (C, D) Natural light intensity. (E, F) Diel changes in gut contents (ng total chlorophyll pigments copepod ${ }^{-1}$ ) and ingestion rate (ng pigments copepod $\left.{ }^{-1} \min ^{-1}\right)$. (G, H) Diel changes in ingestion rate (carbon and \% body carbon) copepod ${ }^{-1} \min ^{-1}$ 
Fig. 10. Acartia tonsa. Mesocosm diel studies, MERL Diel 1 and 2. Copepods fed natural plankton at 12.7 and $13.3^{\circ} \mathrm{C}$. (A, B) Diel changes in clearance rate $(\mu \mathrm{l}$ copepod $^{-1} \min ^{-1}$ ), based on the total and $>10 \mu \mathrm{m}$ phytoplankton size class. (C, D) Gut evacuation curves
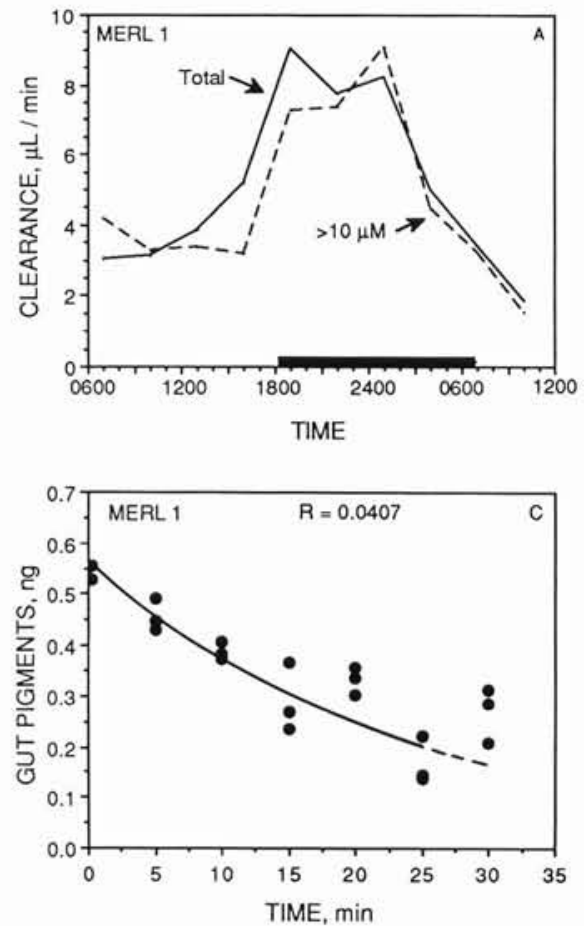
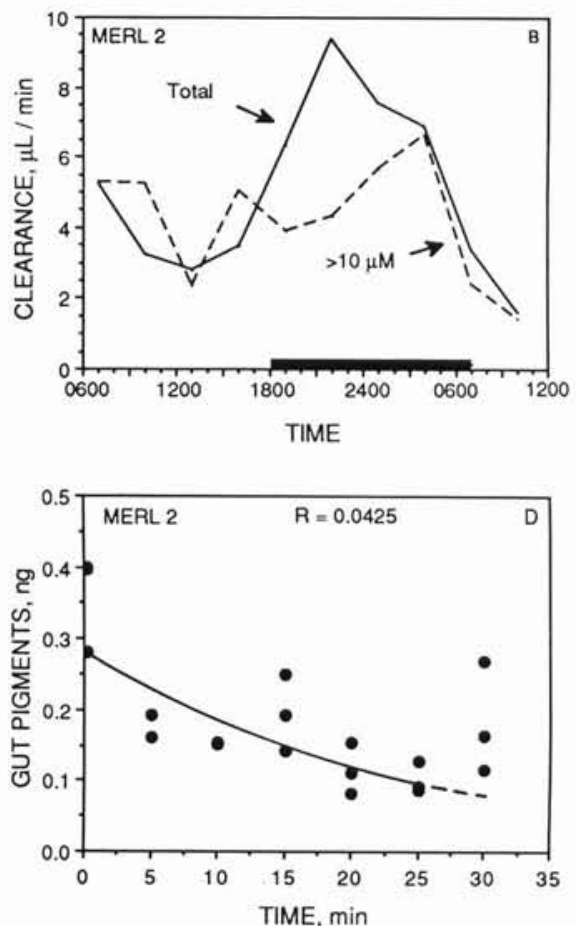

MERL Diel 2

In the second mesocosm experiment on 18 to 19 October, it was dark and cloudy during the morning of the first day, becoming partly cloudy in the afternoon and clearing late in the day; the following morning was overcast and foggy. The overall maximum photon flux density during the daytime $\left(2.23 \mathrm{E} \mathrm{m}^{-2} \mathrm{~h}^{-1}\right)$ was only about half that during the first mesocosm study (Fig. 9D). Mean temperature was $12.7^{\circ} \mathrm{C}$. As in the first experiment, the phytoplankton showed no significant diel trends (Fig. 9B). Mean \pm SE chlorophyll a, phaeopigment and total pigments were $3.15 \pm 0.10$, $1.41 \pm 0.03$, and $4.56 \pm 0.13 \mu \mathrm{g} 1^{-1}$, or slightly lower values than in the first experiment. As before, the phytoplankton were dominated by small flagellates, with $83.8,87.2$, and $84.9 \%$ of the chlorophyll $a$, phaeopigments, and total pigments respectively in the $<10 \mu \mathrm{m}$ size class. Mean phytoplankton carbon:total pigment and nitrogen:total pigment ratios were 129.3 and 19.1 .

The instantaneous gut evacuation rate was 0.0432 $\min ^{-1}$, based on data from 0 to 25 min where, again, about $70 \%$ of gut contents were evacuated (Fig. 10D). Mean gut residence time was $23.1 \mathrm{~min}$. These values were very similar to those obtained in the first mesocosm experiment (MERL Diel 1; Table 1).

As in the first mesocosm experiment there was a diel rhythm in gut contents and feeding rate (Fig. 9F, H). Gut contents and feeding rates as total pigments were somewhat lower than in the first experiment, but when converted to units of carbon and nitrogen were quite similar to those in the earlier study (Fig. 9G, H, Table 3). Maximum ingestion rates were $0.038 \mathrm{ng}$ total pigment, $4.91 \mathrm{ng}$ carbon, and $0.73 \mathrm{ng}$ nitrogen copepod $^{-1} \min ^{-1}$, with the diel amplitude in feeding rate, as before, close to a factor of 3 (Table 2).

Total daily ingestion rates were $35.0 \mathrm{ng}$ total pigment, $4.52 \mu \mathrm{g}$ carbon and $0.67 \mu \mathrm{g}$ nitrogen, or $85 \%$ body carbon and $45 \%$ body nitrogen $\mathrm{d}^{-1}$ (Table 3 ). As in the previous study the best way to estimate clearance rate was uncertain because of the dominance of the $<10 \mu \mathrm{m}$ size fraction in the total phytoplankton biomass, but lower and upper limits, based on the total and $>10 \mu \mathrm{m}$ phytoplankton respectively were: 9.4 and $53.3 \mu \mathrm{l} \mathrm{copepod^{-1 }} \min ^{-1}$ as nighttime maxima, and 7.9 and $53.3 \mathrm{ml}_{\text {copepod }}{ }^{-1} \mathrm{~d}^{-1}$ over the complete diel cycle (Fig. 10B, Table 3).

\section{DISCUSSION}

\section{Temporal variability in feeding behavior}

The most striking aspect of this study was the extreme regularity of the diel feeding pattern in Acartia tonsa, as measured under limiting and non-limiting food levels in the laboratory with cultured algae, and measured under nearly natural conditions in large mesocosms with natural food. The proportional change 
in the feeding rate over the diel cycle was not significantly affected by food quantity or quality, or by temperature within the range tested. Indeed the rhythm continued unchanged even when the copepods were food limited to the point of rapid weight loss and imminent starvation.

The approximately 3 -fold diel amplitude in feeding rate found here was similar to earlier studies with Acartia tonsa, where a 3 - to 4 -fold diel variation in feeding rate was observed. Adult female $A$. tonsa fed Thalassiosira weissflogii at $22.5^{\circ} \mathrm{C}$ in the laboratory exhibited a 2.9-fold variation in gut contents, while in a study of natural plankton the diel amplitude was somewhat higher at about 4- to 4.5-fold (Stearns 1986). In another field study $A$. tonsa gut contents (chlorophyll a + phaeopigment) varied about 3 -fold over the diel cycle (Stearns et al. 1987). Wlodarczyk (1988) found about a 4 -fold diel variation in gut content and feeding rate in adult female $A$. hudsonica in laboratory experiments. Kleppel et al. (1988) reported a 4 -fold range in mean gut contents of field-collected $A$. tonsa at a mean temperature of $19.6^{\circ} \mathrm{C}$. Kiørboe et al. (1985) found a 3.7-fold change in gut contents of mixed $A$. tonsa and A. longiremis, but curiously the diel pattern was reversed, with lower gut content at night. It is not clear whether this phenomenon was real, or was related to the fact that mixed stages (with differing gut capacity) of the 2 species were measured. Daro (1988) described a strong nocturnal periodicity, and Tiselius (1988) a rather inconclusive diel pattern, in mixed stages of $A$. clausi and A. longiremus, but interpretation of these results is also uncertain because of the mixed composition of the plankton samples.

The diel feeding rhythm in Acartia tonsa appears to be controlled endogenously. Stearns (1986) demonstrated that while the feeding rate in A. tonsa was strongly influenced by light intensity, the feeding rhythm persisted in complete darkness. These results, together with the constancy of the amplitude of the feeding rhythm, indicate that the diel feeding rhythm is a fundamental behavior pattern in A. tonsa.

Although the amplitude of the diel rhythm appears to be stable, Acartia tonsa nonetheless adjusts its mean daily clearance and ingestion rates according to food abundance. The functional relationship between total daily ingestion and food concentration is best described by an asymptotic, curvilinear function such as an Ivlev curve (Bartram 1980, Deason 1980b, Kiørboe et al. 1985); this implies that mean clearance rate is continuously modified as food level changes. Clearance rate in A. tonsa reaches its maximum while still within the range of limiting food, rapidly declines at lower food concentration, and declines more gradually with higher food concentration (Kiørboe et al. 1985, Paffenhöfer \& Stearns 1988). It is uncertain whether $A$. tonsa ceases feeding completely at a lower food threshold as was shown for A. hudsonica (Wlodarczyk 1988).

Cinematic observations of individual copepods have shown that Acartia is an intermittent feeder that adjusts its feeding effort in relation to food availability (Piontkovskii \& Petipa 1976 cited in Paffenhöfer \& Stearns 1988, Rosenberg 1980, Paffenhöfer \& Stearns 1988). These investigators noted a great deal of individual variation in feeding behavior on time scales $\leq 1 \mathrm{~s}$. Longer-term variation in feeding behavior, in the order of minutes (comparable to the time scales associated with gut evacuation), is indicated by the wide range in gut contents measured on individual copepods (Mackas \& Burns 1986, Båmstedt 1988, Kleppel et al. 1988, this study). Copepods have several means of altering their feeding rates. These include changing the proportion of time spent feeding, swimming, and resting; altering the frequency of mouthpart movement; and changing the efficiency with which particles are captured (Rosenberg 1980, Cowles \& Strickler 1983, Mackas \& Burns 1986, Price \& Paffenhöfer 1986, Paffenhöfer \& Stearns 1988). It appears that Acartia employs all of these.

Studies with Calanus helgolandicus have shown that the cells of the gut epithelium associated with digestion of the food may become exhausted during feeding, possibly requiring a non-feeding period of recovery during which gut cells are replenished (Nott et al. 1985). These investigators proposed that cyclical changes in the digestive function of the gut over periods of several hours could induce corresponding cycles in voluntary food intake, assimilation efficiency, or both. If correct, this hypothesis may provide a physiological basis for the cyclical feeding behavior in $C$. pacificus observed by Mackas \& Burns (1986) and for the apparent bimodal nocturnal feeding pattern in $C$. finmarchicus by Simard et al. (1985).

Thus the deceptively simple curve describing total daily ingestion rate in relation to food abundance is actually a composite of several behavior patterns operating on different time scales: alternate periods of feeding, passive sinking and swimming, on the scale of milliseconds to seconds, coupled with longer term variation in feeding rate on scales comparable to the mean gut residence time (minutes), and a possible cyclic variation in gut function associated with depletion/ replenishment of epithelial cells (hours?), upon which is superimposed $\mathrm{a} \sim 3$-fold change in clearance rate over the diel cycle.

\section{Daily ingestion rate}

Daily ingestion rates in the 2 laboratory experiments (Laboratory feeding, Expts 1 and 2) at $20^{\circ} \mathrm{C}$, using 
cultured Thalassiosira weissflogii as food, were in good agreement; results from the 2 mesocosm experiments (Mesocosm diel studies, MERL Diel 1 and 2) at 12 to $13^{\circ} \mathrm{C}$ were also internally consistent. Daily ingestion rates of $148 \%$ body carbon and $104 \%$ body nitrogen were found at $20{ }^{\circ} \mathrm{C}$, and 74 to $85 \%$ body carbon, and 40 to $45 \%$ body nitrogen at $\sim 13{ }^{\circ} \mathrm{C}$ (Table 3 ). The ingestion rate at $20^{\circ} \mathrm{C}$ was similar to that found by Kiørboe et al. (1985) for Acartia tonsa fed Rhodomonas baltica at $18^{\circ} \mathrm{C}\left(150 \%\right.$ body carbon $\left.\mathrm{d}^{-1}\right)$. Present results with $A$. tonsa were also consistent with those from $A$. hudsonica fed $T$. constricta, where maximum daily ingestion rates were calculated to be $122 \%$ body carbon and $87 \%$ body nitrogen at $20^{\circ} \mathrm{C}$, and $70 \%$ body carbon and $53 \%$ body nitrogen at $13{ }^{\circ} \mathrm{C}$ (E. G. Durbin \& A. G. Durbin unpubl.; Table 3, using general equation for all temperatures). However Deason (1980b) obtained much higher maximum daily feeding rates in $A$. hudsonica fed the chain forming diatom Skeletonema costatum, ranging from 84 to $660 \%$ body carbon and 42 to $250 \%$ body nitrogen over a temperature range of 5 to $15^{\circ} \mathrm{C}$.

\section{Evacuation rates}

Replicate measurements of gut evacuation rate at the 2 temperatures were in good agreement. Mean value of $R$ at $20^{\circ} \mathrm{C}$ was $0.090 \mathrm{~min}^{-1}$, while the mean for ca $13^{\circ} \mathrm{C}$ was $0.042 \mathrm{~min}^{-1}$. Published gut evacuation rates at similar temperatures vary, reflecting not only differences in the species being investigated, but probably differences in the physiological condition of both the copepods and their food. Our data at $13^{\circ} \mathrm{C}$ were similar to those of Kiørboe \& Tiselius (1987) for Acartia tonsa at $13.7^{\circ} \mathrm{C}\left(0.048 \mathrm{~min}^{-1}\right.$ for copepods in filtered seawater [to $70 \%$ gut evacuation], and $0.045 \mathrm{~min}^{-1}$ for continuously fed copepods). Our estimates for $A$. tonsa were somewhat lower than those of Wlodarczyk (1988) for $A$. hudsonica at $12^{\circ} \mathrm{C}\left(0.050 \mathrm{~min}^{-1}\right)$ and Ellis \& Small (1989) for Calanus marshallae at $10^{\circ} \mathrm{C}\left(0.059 \mathrm{~min}^{-1}\right.$, according to their Table 3, mean for all treatments over 0 to $20 \mathrm{~min}$ ). Our data were slightly higher than values computed from $Q_{10}$ relationships given for several other copepod species, i.e. for Centropages hamatus, we compute the $\mathrm{Q}_{10}$ for $\mathrm{R}=3.8$ from Fig. 2 in Kiørboe et al. (1982), yielding $\mathrm{R}=0.031 \mathrm{~min}^{-1}$ at $13^{\circ} \mathrm{C}$ and 0.080 $\min ^{-1}$ at $20^{\circ} \mathrm{C}$; for Eudiaptomus graciliodes, $\mathrm{Q}_{10}=4.1$ (Christofferson \& Jespersen 1986), yielding $\mathrm{R}=0.028$ $\min ^{-1}$ at $13^{\circ} \mathrm{C}$ and $0.074 \mathrm{~min}^{-1}$ at $20^{\circ} \mathrm{C}$; and for Temora longicornis, according to Table III, Eq. 3 in Dam and Peterson (1988), $\mathrm{R}=0.037 \mathrm{~min}^{-1}$ at $13^{\circ} \mathrm{C}$ and 0.068 $\min ^{-1}$ at $20^{\circ} \mathrm{C}$.

However Stearns et al. (1987) reported a rather low gut passage time of $30 \mathrm{~min}$, corresponding to an $\mathrm{R}$ of
$0.033 \mathrm{~min}^{-1}$, for Acartia tonsa at $25^{\circ} \mathrm{C}$. The copepods were collected from the field and held in the laboratory for about $24 \mathrm{~h}$ before being used for the evacuation experiment. The investigators did not mention whether the copepods were given supplemental food during this period; possibly the low R-value was a consequence of inadequate nutrition either in the laboratory or in the field prior to the experiment. Sosnowski et al. (1979) observed degeneration of the digestive system in field collected $A$. tonsa during periods of low natural food availability, indicating that the digestive system atrophies under food limitation. Such variation in the physiological state of the copepods may contribute to the variability in gut evacuation rates which have been reported from different studies.

The instantaneous evacuation rate in Acartia tonsa did not change significantly over the diel cycle, despite the differing initial gut contents at night (2.6 ng pigment copepod ${ }^{-1}$ ) and day (1.4 ng pigment copepod ${ }^{-1}$ ). These results were in accordance with those of Head (1986) for Calanus glacialis. The choice of the evacuation rate affects the estimated ingestion rate, but not the amplitude of the diel feeding pattern. Thus for example in our experiment at 3 food levels (Lab diel feeding, Expt 2), even if the evacuation rate were depressed at the lowest food level, requiring that the calculated ingestion rates be reduced accordingly (multiply the gut content data in Tables 2 and 3 by the new R-value), such a correction would not affect our conclusion that the amplitude of the diel feeding pattern was the same at all 3 feeding levels (e.g. Figs. 6B and $7 \mathrm{~A}$ ).

The exponential decline in gut contents with time in non-feeding copepods implies that the instantaneous evacuation rate is independent of the amount of food in the gut (indeed it is this property that makes it possible to estimate feeding rate in situ from simple measurements of gut contents and evacuation rate). In most studies this assumption seems warranted, over a wide range of gut contents, e.g. in Calanus marshallae, evacuation rates were not significantly different at feeding levels from 500 to 4000 cells Thalassiosira weissflogii $\mathrm{ml}^{-1}$, in which the initial gut pigment contents ranged over more than an order of magnitude $(0.7$ to $16 \mathrm{ng}$ total pigments copepod ${ }^{-1}$ ) (Ellis \& Small 1989). However Dagg \& Walser (1987) found that evacuation rates in Neocalanus plumchrus were reduced at low food levels. For this reason, the range of gut contents over which $\mathrm{R}$ is determined should be similar to those that occur in the corresponding feeding studies, to ensure that the assumption of exponential gut evacuation is valid for the range of gut contents observed in feeding copepods. In the present study the lowest observed gut contents over the diel cycle fell within the exponential phase of the corresponding gut evacuation 
experiment, indicating that the same evacuation rate was applicable throughout the same experiment.

Removal of copepods from food does not appear to affect evacuation rates, as long as the measurements are not continued beyond the stage of about $70 \%$ gut evacuation. Kiørboe \& Tiselius (1987) demonstrated that evacuation rates in Acartia tonsa measured in filtered seawater up to the point of $70 \%$ gut evacuation were comparable to rates of copepods that were continuously fed. Ellis \& Small (1989) using chlorophyll pigments and ${ }^{68}$ germanium as twin tracers of gut evacuation in Calanus marshallae also demonstrated that evacuation rate in fed and unfed copepods were not significantly different. Christofferson \& Jespersen (1986) found no difference in the evacuation rates of Eudiaptomus graciloides measured on copepods transferred to filtered seawater, and those that were continuously fed.

We have frequently observed that in gut evacuation experiments, the slope of the evacuation curve declines after about 70 to $80 \%$ of the gut contents were eliminated, indicating a decline in R. Kiørboe \& Tiselius (1987), Dam \& Peterson (1988), and Ellis \& Small (1989) also observed a reduction in $\mathrm{R}$ in the late stage of evacuation (but see Christofferson \& Jespersen 1986, who found no significant decline in gut evacuation rate over time in their study with Eudiaptomus graciloides). In an exponential process, differently sized meals reach the same percentage of gut evacuation at the same time; this time is dependent upon R. The fact that evacuation maintains the same exponential rate until gut contents reach a certain percentage of evacuation indicates there is no single threshold gut content amount below which evacuation automatically declines. Since copepods are intermittent feeders, it may be that a periodic ingestion of fresh food is needed to restimulate the gut after a time interval sufficient for most of the previous meal to be evacuated.

Further, a reduction in $\mathrm{R}$ near the end of gut evacuation may also be an experimental artifact related to variability in individual gut contents, and the analytical limit of detection as gut contents approach zero (Olson \& Mullen 1986). An example of such an effect is shown in Fig. 11. In Fig. 11A, a hypothetical gut evacuation curve is shown in which the individual variance in gut contents $=0$, initial gut content $=1.0 \mathrm{ng}$ copepod $^{-1}$, and $\mathrm{R}=0.0347 \mathrm{~min}^{-1}$. The true gut evacuation rate can be obtained from the slope of this relationship; the regression $r^{2}=1.0$. In the next example (Fig. 11B), the initial gut contents of 10 copepods are assumed to vary randomly over a range of 0.14 to $2.3 \mathrm{ng}$ copepod $^{-1}$, with $\mathrm{R}=0.0347$ as before. As long as all values of gut pigments can be analytically detected, and the original variance in gut content data thereby preserved, the correct value of $\mathrm{R}$ will also be obtained from the slope of this relationship, although the regression $\mathrm{r}^{2}(0.41)$ is lower because of the scatter in the data. The third example (Fig. 11C) demonstrates the consequence of an analytical limit of detection (or an assumed 'background' fluorescence), arbitrarily chosen to be $0.1 \mathrm{ng}$ copepod $^{-1}$, upon the estimation of R. As gut contents decline towards this limit, the variance of the data is artificially truncated, with the lowest values corresponding to copepods with initially lower gut contents non-detectable (data representing 'empty' guts must be deleted from the regression because the exact time the gut became 'empty' is not known). Because only the copepods with initially high gut contents are represented, the slope of the evacuation curve in the later stage of the experiment declines, producing the false impression that $\mathrm{R}$ has declined as well (in the present
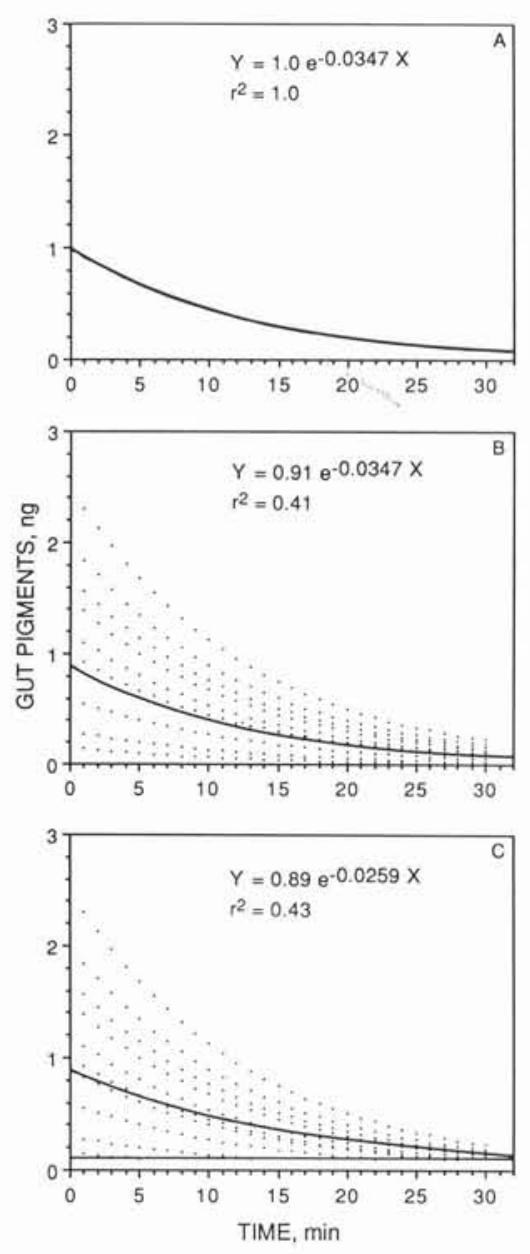

Fig. 11. Acartia tonsa. Effects of variability in initial gut contents $\left(\mathrm{S}_{0}\right)$ and of an analytical lower limit for the detection of pigments, upon the estimation of the instantaneous gut evacuation rate $\left(\mathrm{R} \mathrm{min}^{-1}\right)$ from the slope of the regression of gut contents vs time. True $\mathrm{R}=0.0347 \mathrm{~min}^{-1}$ in each case. (A) No variability in $\mathrm{S}_{0}$, no lower limit of detection. (B) Variable $\mathrm{S}_{0}$, no lower limit of detection. (C)-Variable $\mathrm{S}_{0}$ with an analytical lower limit $=0.1 \mathrm{ng}$ total pigments 
example, $\mathrm{R}$ estimated from truncated data $=0.0259$, about $25 \%$ lower than the true value). In an evacuation experiment, the point at which such an artifact will significantly affect the estimation of $\mathrm{R}$ will depend upon (1) the accuracy of the analytical technique for measuring low levels of gut pigments (the problem occurs sooner in an experiment, and at a higher gut content level, when analytical sensitivity is poor); (2) the degree of individual variability in gut contents (especially the proportion of copepods with initially low gut contents that will quickly reach the detection limit); and (3) the mean initial gut content (in a low food experiment, gut contents will approach the detection limit sooner than in a high food experiment, possibly giving the impression that $\mathrm{R}$ is lower at low food abundance than at high food).

Thus it is not clear whether a decline in $\mathrm{R}$ near the end of a gut evacuation experiment is biologically meaningful, or an experimental artifact. It would appear that the initial phase of the gut evacuation curve should most closely represent the gut evacuation of copepods in situ, because it is least likely to be biased by prolonged separation of the animals from their food, and by truncation of the data as gut contents approach the limits of detection. In our experiments, for the sake of consistency we calculated $\mathrm{R}$ only from data up to the point of 70 to $80 \%$ gut evacuation, regardless of whether R seems to decline thereafter. Difficulties reported by earlier workers in fitting an exponential curve to evacuation data (e.g. Baars \& Oosterhuis 1984, Wang \& Conover 1986) are probably related to the fact that they continued the measurements until the gut was nearly empty. This practice may seriously underestimate the true gut evacuation rate in actively feeding copepods.

\section{Gut fluorescence as an estimator of feeding rate}

There is at present some controversy about whether gut pigments provide a quantitative measure of feeding rate, or whether chlorophyll pigments are degraded to non-fluorescent compounds in the gut, with consequent underestimation of feeding rate (Helling \& Baars 1985, Conover et al. 1986, Wang \& Conover 1986, Head 1988). However, a number of sources of error are present in both the gut content method for estimating ingestion, and the cell count method to which it is frequently compared, making inter-comparisons difficult and perhaps leading to apparent losses of pigment in the gut. The cell count method is indirect, relying on changes in cell numbers in the grazer jar as corrected for phytoplankton growth. Potential problems include the adequate estimation of phytoplankton growth by using control jars; container effects during the relatively long-term experiments (Roman \& Rublee 1980); and fragmentation of phytoplankton cells during grazing (Paffenhöfer \& Knowles 1978, Deason 1980a, Tande \& Slagstad 1985, Roy et al. 1989), which may cause ingestion to be overestimated. The gut content method has the advantage of being a direct measurement on the copepods themselves, requiring a minimum of handling. However only the very recent feeding history of the copepods is measured; longerterm estimates of ingestion require regular measurements of gut content. Variations in ingestion rate between sampling intervals are a source of error. The calculated ingestion rate is also very sensitive to the gut evacuation rate. The rapidity of gut evacuation, especially at higher temperatures $\left(\sim 9 \% \mathrm{~min}^{-1}\right.$ at $20^{\circ} \mathrm{C}$ in this study) could itself contribute towards underestimation of feeding rate in the gut pigment method in comparison with the cell count method, since gut contents continue to be evacuated during collection and sorting of the plankton. This problem is reduced if the copepods are anesthetized or otherwise immobilized (e.g. by freezing) prior to sorting, but in the present study the probable loss in gut contents due to evacuation during the collection time of $\sim 30 \mathrm{~s}$ was sufficient to account for half of the approximately $8.2 \%$ lower ingestion rate computed from the gut pigment method, compared to the cell count method.

The present study was not directed towards answering the question of whether gut pigments provide a quantitative measure of feeding rate, but we found good agreement between daily ingestion as measured by gut pigments, and cell count method. Dagg \& Grill (1980) and Kiørboe et al. $(1982,1985)$ also found no systematic difference between the 2 methods. Dagg \& Walser (1987) reported an average $11 \%$ pigment loss. Pasternak \& Drits (1988) concluded that pigments were not destroyed. Ellis \& Small (1989) did not investigate the question of pigment degradation in their study of gut evacuation in Calanus marshallae, but the fact that the exponential evacuation of chlorophyll pigments was not significantly different from that of the ${ }^{68} \mathrm{ger}$ manium provided indirect evidence that chlorophyll pigments were not degraded in the gut (otherwise, due to the combined effects of evacuation and destruction, chlorophyll pigments should have disappeared from the gut more quickly than germanium). Kiørboe \& Tiselius (1987) compared 3 methods of estimating ingestion in Acartia tonsa. Ingestion rates based on a pigment budget, after correction for secondary loss of pigments from fragmented fecal pellets, were $8 \%$ lower than rates obtained from cell counts. Ingestion rates from the silica ratio method applied to apparently undamaged fecal pellets were $11 \%$ lower; while no systematic difference was found in a comparison of ingestion estimates from gut filling rate measured by 
pigments, and changes in the concentration of algae. Available information from Acartia spp. and a number of other species thus does not support the contention that the gut pigment method seriously underestimates feeding rate.

A significant destruction of pigment in the copepod gut has not been demonstrated directly, but has been inferred when ingestion estimated from gut pigment was lower than by another method (Wang \& Conover 1986, Head 1988) or when ingested pigment could not quantitatively be recovered in the gut or feces (Helling \& Baars 1985, Conover et al. 1986, Head 1988). The models used for several of these intercomparisons (e.g. Wang \& Conover 1986, Dagg \& Walser 1987) have stringent requirements for constancy of feeding rates during the experimental period, and are sensitive to experimental error or variability in the data. Unless these requirements are met, a close correspondence between different methods for estimating evacuation or feeding rates might not be expected. For example, in the study by Wang \& Conover (1986) ingestion rate from cell counts during a 2 to $3 \mathrm{~h}$ experiment was assumed to be equivalent to that estimated from the final gut contents, under the assumption that feeding rate had been constant over the entire experimental period. However both gut content data and evacuation rate measurements appear to have been quite variable, and the central assumption that feeding rates measured over such different time scales $(2$ to $3 \mathrm{~h}$ for cell numbers vs minutes for gut contents) were equivalent seems doubtful. Dagg \& Walser (1987) made a similar assumption that feeding rate was constant during their experiments, but by recovering the fecal pellets as well as the final gut contents they obtained a more complete measurement of the total ingested pigment, for comparison with the decline in cell numbers during an experiment.

The use of an inappropriate gut evacuation rate may cause poor agreement between the gut pigment method and other means of estimating ingestion rates. Where evacuation rate measurements were continued until the gut was nearly empty (Baars \& Oosterhuis 1984, Wang \& Conover 1986, Head 1988), both R and the corresponding ingestion rates could have been significantly underestimated. In the comparison by Head (1988) of ingestion rates estimated from gut pigments and the decline in phytoplankton biomass, the gut evacuation rate, which was critical for a valid comparison, was not actually determined in that experiment but was taken from an earlier field study. Uncertainty about the R-value used for the comparison casts doubt upon any conclusions regarding possible pigment destruction.

In some studies it has been assumed that gut evacuation did not occur, and ingestion was equated with gut contents without a correction for R. In their study Roy et al. (1989) assumed that no gut evacuation occurred in Calanus helgolandicus and Temora longicornis during an experimental period of $45 \mathrm{~min}$ at $15^{\circ} \mathrm{C}$, but no supporting evidence was supplied. A low recovery of pigment in the copepods was taken as evidence for either loss of pigments from cellular debris, or pigment destruction in the copepod gut. However loss of gut contents to evacuation, with subsequent loss of fecal material in finescale debris, is an alternative explanation for their results. Direct measurements of gut evacuation rate imply that mean gut residence times are much shorter than assumed by Roy et al. for example in C. marshallae at $10^{\circ} \mathrm{C}$ where $\mathrm{R}=0.059 \mathrm{~min}^{-1}$, the mean gut residence time $=17 \mathrm{~min}$ (Ellis \& Small 1989); in T. longicornis at $15^{\circ} \mathrm{C}$ where $\mathrm{R}=0.044 \mathrm{~min}^{-1}$, the mean gut residence time $=23 \mathrm{~min}$ (Dam \& Peterson 1988). Similarly, the assumption by Libourel Houde \& Roman (1987) that gut evacuation did not occur during 45 min experiments with Acartia tonsa fed radiolabelled algae at $20^{\circ} \mathrm{C}$ seems incorrect, in view of the rapid gut evacuation rates found by Kiørboe \& Tiselius (1987) and the present study, where at $20^{\circ} \mathrm{C}, \mathrm{R}=\sim 0.09 \mathrm{~min}^{-1}$ and mean gut residence time $=\sim 11 \mathrm{~min}$. The surprisingly low maximum ingestion rates of $\sim 10 \%$ body carbon $\mathrm{d}^{-1}$ found by Houde \& Roman may reflect unquantified losses of radiolabel not only to gut evacuation, but also to respiration and to spawning of eggs. In experiments of more than a few minutes' duration, the assumption that gut evacuation does not occur should be treated with caution, since failure to correct for evacuation when it occurs will significantly underestimate ingestion rate.

In studies attempting to balance a chlorophyll pigment budget using fecal pellets (e.g. Shuman \& Lorenzen 1975, Downs \& Lorenzen 1985, Helling \& Baars 1985, Conover et al. 1986, Dagg \& Walser 1987, Head 1988) several factors may lead to low recovery of pigments from fecal pellets and bias results towards apparent pigment destruction. Recovery of even an inert tracer such as silicon is usually incomplete (Tande \& Slagstad 1985, Conover et al. 1986), apparently because cell fragmentation during feeding and breakage of fecal pellets produces finescale debris that is not retained upon the nylon screen or glass fiber filters typically used to collect fecal material at the end of an experiment. Chloroplasts released from broken phytoplankton cells (Roy et al. 1989) and fecal pellets (Nott et al. 1985, Kiørboe \& Tiselius 1987) are similarly apt to be lost, and may be interpreted as evidence of pigment destruction rather than a consequence of incomplete recovery of material.

Kiørboe \& Tiselius (1987) demonstrated that fragmentation of fecal pellets, whether by mechanical damage or re-ingestion by copepods during the course of an 
experiment, led to significant losses of both pigment and silicon content. Pellets lost chlorophyll pigments more rapidly than silicon. Such differential losses are potential sources of error in studies using the silicon ratio technique (Tande \& Slagstad 1985) to assess pigment degradation (Conover et al. 1986, Head 1988), since that method assumes that the fecal pellet accurately represents the contents of the copepod's gut. A differential loss of pigment will mimic pigment destruction. A further problem is that the silicon ratio method assumes that the pellet, once evacuated from the copepod, is inert (recall that a pellet may reside only a few minutes in the gut of a copepod, but may be left for many hours in an experimental vessel before collection and analysis). However, as shown by Nott et al. (1985) fecal pellets contain digestive enzymes and bacteria, and it is possible that the organic contents continue to break down after egestion of the pellet. Such a postevacuation loss would also mimic pigment destruction in the copepod gut. Kiørboe \& Tiselius (1987) concluded that failure to correct for secondary pigment losses from fecal pellets could explain the apparent high pigment destruction in studies by Shuman \& Lorenzen (1975) and Helling \& Baars (1985). Similar reasoning could be applied to other studies in which fragmentation of fecal pellets also seems possible either because of long experimental duration (Conover et al. 1986) or crowding of the experimental copepods (Head 1988).

In summary, evidence regarding pigment destruction in the copepod gut is conflicting, and direct evidence of destruction is lacking at present. The various methods used to examine the problem thus far require a complex series of measurements, and are subject to a variety of errors that are not always easy to quantify. The twin tracer technique used by Ellis \& Small (1989) to investigate gut evacuation rate might provide a useful alternative to other methods of investigating pigment destruction. A comparison of the slopes of the evacuation curves for pigment and ${ }^{68}$ germanium should provide a direct measure of whether such destruction occurs. The measurements are made directly on the copepods themselves, without the need to measure ingestion rate or to collect fecal pellets. Further, the time scale of the measurements suitably reflects the time that the food is actually present in the copepod, and does not require extended experimental incubations in order to make the necessary measurements. The principal assumptions that would need to be verified are that the inert tracer is not absorbed, and that both tracer and pigment are processed at the same rate in the copepod's gut (i.e. that the digestible portions of the food are not evacuated sooner than indigestible portions as seen for example in fishes; Hansel et al. 1988).

\section{Adaptive significance of diel rhythms}

The adaptive significance of diel migration has been extensively discussed - see for example recent reviews by Haney (1988) and Frost (1988) - but the adaptive value of diel feeding rhythms, and the extent to which such rhythms persist under different environmental conditions, are less well known. Diel migrations may serve several functions but there is much evidence that they represent a compromise between the conflicting requirements of feeding and predator avoidance. A nocturnal upward movement by zooplankton brings them into richer grounds for feeding and spawning (Gauld 1953, Marshall \& Orr 1955, Williams \& Conway 1984), whereas a diurnal downward movement reduces their vulnerability to visual predators (Zaret \& Suffern 1976, Fancett \& Kimmerer 1985, Bollens \& Frost 1989a, b) and, perhaps, damage from light (Hairston 1979, Ringelberg et al. 1984). 'Reverse' migrations, when the plankton move deeper by night, have been interpreted as avoidance of non-visual, tactile predators (Ohman et al. 1983). One of the most interesting characteristics of diel migratory behavior is its extraordinary plasticity, perhaps reflecting ontogenetic development (Huntley \& Brooks 1982, Brooks \& Mullin 1983, Williams \& Conway 1984, Ambler \& Miller 1987), seasonal changes (Nicolajsen et al. 1983, Williams \& Conway 1984, Båmstedt \& Tande 1988, Williams 1988), and local conditions of food availability and predation pressure (Bohrer 1980, Boyd et al. 1980, Dagg 1985, Frost 1985, 1988, Johnsen \& Jakobsen 1987, Gliwicz \& Pijanowska 1988, Bollens \& Frost 1989b, Dagg et al. 1989). By contrast, diel feeding rhythms seem to be a more persistent and stable behavior, occurring both in the presence of diel migration (e.g. in Calanus: Gauld 1953, Daro 1980, Simard et al. 1985, Båmstedt \& Tande 1988, Runge \& Ingram 1988, Dagg et al. 1989; Pseudocalanus: Mackas \& Bohrer 1976, Daro 1985, Harding et al. 1986; Acartia: Stearns 1986) and in its absence (Calanus: Dagg 1985, Daro 1985, 1988, Head et al. 1985; Pseudocalanus: Daro 1985, 1988; Acartia: Daro 1988).

These results imply that diel rhythms in feeding and migration are controlled separately. While the diel feeding rhythm in Acartia tonsa was shown to be endogenous, the nocturnal vertical migrations were not under endogenous control, but were triggered by relative changes in quantal light intensity (Stearns \& Forward 1984a, b, Stearns 1986). The level of light adaptation controlled the responsiveness by $A$. tonsa to the light stimulus. Field studies further confirmed that diel feeding patterns are regulated independently of vertical migration in A. tonsa; copepods found at surface and mid-depths during daytime exhibited a nocturnal feeding periodicity comparable to that seen in 
copepods undergoing the characteristic diel vertical migration, and located near the bottom during the daytime (Stearns 1986). Similarly, Head et al. (1985) concluded that diel rhythms in feeding and vertical migration in Calanus hyperboreus and C. glacialis are controlled independently, and that both are mediated by light. The characteristic activity patterns of different species also seem to be controlled independently of a diel feeding rhythm. For example, Mackas \& Burns (1986) found that short-term feeding rate was correlated with swimming activity in C. pacificus, which exhibited periodicity of a few hours in feeding and activity levels, while continuing to maintain an overall diel feeding rhythm as well. In contrast, Metridia pacifica maintained a diel feeding periodicity without noticeably changing its activity levels.

While diel feeding rhythms have been observed under conditions of low natural food availability (Mackas \& Bohrer 1976, Dagg \& Grill 1980, Hayward 1980, Head et al. 1984, Simard et al. 1985, Batchelder 1986, Daro 1988, Runge \& Ingram 1988), several reports have suggested that feeding rhythms may disappear when food is limiting (Dagg 1985, Dagg \& Walser 1987, Daro 1988 for Pseudocalanus). Loss of the feeding rhythm would imply either that food limitation has over-ridden other factors governing diel feeding rhythms and induced continuous feeding, or that a synchronized population-wide feeding rhythm has given way to intermittent, asynchronous feeding among individuals (Boyd et al. 1980, Båmstedt 1984, but see Head et al. 1985). Although present results suggest that at low food abundance, the diel amplitude in feeding rate is comparable to that at high food concentration, the actual ingestion rates are low. Thus in the field, a diel pattern may be difficult to distinguish against the background variability associated with spatial heterogeneity, sampling error, and individual variation in gut contents, which remains large even when feeding rate is low. Laboratory studies would be useful to confirm the apparent loss of the diel rhythm under low food conditions in the field, where a diel rhythm may be difficult to detect even when it exists.

Present results demonstrate a strongly ingrained diel feeding rhythm in Acartia tonsa, which restricted its feeding during the daytime under severely limiting food conditions and rapid weight loss. An invariant nocturnal feeding rhythm was also found by Marcus (1988) in Labidocera aestiva, which when provided with food at different times during a $12 \mathrm{~h}$ light : $12 \mathrm{~h}$ dark cycle was unable to adjust its feeding schedule according to the time at which food was available. As a consequence, fecundity in L. aestiva provided with food only at night was about twice that of animals fed only during the day.

The persistence of diel feeding rhythms under limit- ing food conditions, and the endogenous component of the behavior, imply that the selective pressure for this behavior is strong. It has been suggested that copepod feeding behavior, especially at low food abundance, reflects some form of energy optimization strategy (Lam \& Frost 1976, Lehman 1976, Koehl \& Strickler 1981, Cowles \& Strickler 1983, Price et al. 1983, Price \& Paffenhöfer 1986). Such arguments have also been advanced for plankton-feeding fishes (Ware 1975, Durbin \& Durbin 1983). However a diel feeding rhythm would appear inconsistent with an energy optimization strategy that predicts a single, optimal feeding rate at each food concentration. In particular, at low food concentration the voluntary restriction of feeding during the day would appear to exacerbate the problem of insufficient food. However, if the increased swimminc activity and darkened gut associated with feeding make a zooplankter more visible, and hence vulnerable, to visual predators then a reduction in feeding activity during the daytime might enhance survival (Dagg et al. 1989). This behavior might be particularly important when plankton form non-migratory layers near the surface (e.g. Daro 1988) where their vulnerability to diurnally active visual predators would seem to be great. Diel feeding rhythms are thus consistent with the hypothesis that predation has had a major role in shaping zooplankton behavior.

Acknowledgements. We thank Robert Campbell, Einar Hjorleifsson, and Sharon Larimer for help in sorting the copepods for the experiments, and Celia Chen for assistance in the carbon and nitrogen determinations. We also thank Candace Oviatt of the Marine Experimental Research Laboratory, for providing the opportunity to carry out the experiments in the MERL mesocosm tanks; Eric Klos for assistance in setting up and maintaining the mesocosms; Jonathan Hopkins for the design and construction of the mixing paddles and electronic controls, and Theodore Smayda for the use of his carbonnitrogen analyzer. We further thank 3 anonymous reviewers for helpful comments which significantly improved the manuscript. This research was supported by National Science Foundation, Biological Oceanography Program, grant OCE 8214836.

\section{LITERATURE CITED}

Ambler, J. W. (1985). Seasonal factors affecting egg production and viability of eggs of Acartia tonsa Dana from East Lagoon, Galveston, Texas. Estuar. Coast. Shelf Sci. 20: $743-760$

Ambler, J. W. (1986). Effect of food quantity and quality on egg production of Acartia tonsa Dana from East Lagoon, Galveston, Texas. Estuar. Coast. Shelf Sci. 23: 183-196

Ambler, J. W., Miller, C. B. (1987). Vertical habitat-partitioning by copepodites and adults of subtropical oceanic copepods. Mar. Biol. 94: 561-577

Baars, M. A., Helling, G. R. (1985). Methodological problems in the measurement of phytoplankton ingestion rate by gut fluorescence. Hydrobiol. Bull. 19: 81-88

Baars, M. A., Oosterhuis, S. S. (1984). Diurnal feeding rhythms 
in North Sea copepods measured by gut fluorescence, digestive enzyme activity and grazing on labeled food. Neth. J. Sea Res. 18 (1/2): 97-119

Båmstedt, U. (1984). Diel variations in the nutritional physiology of Calanus glacialis from Lat. $78^{\circ} \mathrm{N}$ in the summer. Mar. Biol. 79: 257-267

Båmstedt, U. (1988). Ecological significance of individual variability in copepod bioenergetics. Hydrobiologia 167/168: 43-59

Båmstedt, U., Tande, K. (1988). Physiological responses of Calanus finmarchicus and Metridia longa (Copepoda: Calanoida) during the winter-spring transition. Mar. Biol. 99: $31-38$

Bartram, W. C. (1980). Experimental development of a model for the feeding of neritic copepods on phytoplankton. J. Plankton Res. 3: 25-51

Batchelder, H. P. (1986). Phytoplankton balance in the oceanic subarctic Pacific: grazing impact of Metridia pacifica. Mar. Ecol. Prog. Ser. 34: 213-225

Beckman, B. R., Peterson, W. T. (1986). Egg production by Acartia tonsa in Long Island Sound. J. Plankton Res. 8: 917-925

Bohrer, R. N. (1980). Experimental studies on diel vertical migration. In: Kerfoot, W. C. (ed.) Evolution and ecology of zooplankton communities. University Press of New England, Hanover, New Hampshire, p. 111-121

Bollens, S. M., Frost, B. W. (1989a). Zooplanktivorous fish and variable diel vertical migration in the marine planktonic copepod Calanus pacificus. Limnol. Oceanogr. 34: 1072-1083

Bollens, S. M., Frost, B. W. (1989b). Predator-induced diel vertical migration in a planktonic copepod. J. Plankton Res. 11: 1047-1065

Boyd, C., Smith, S., Cowles, T. (1980). Grazing patterns of copepods in the upwelling system off Peru. Limnol. Oceanogr. 25: 583-596

Brooks, E. R., Mullin, M. M. (1983). Diel changes in the vertical distribution of biomass and species in the Southern California Bight. CalCOFI Rep. 24: 210-215

Christofferson, K., Jespersen, A.-M. (1986). Gut evacuation rates and ingestion rates of Eudiaptomus graciloides measured by means of the gut fluorescence method. J. Plankton Res. 8: 973-983

Conover, R. J., Durvasula, R., Roy, S., Wang, R. (1986). Probable loss of chlorophyll-derived pigments during passage through the gut of zooplankton, and some of the consequences. Limnol. Oceanogr. 31: 878-887

Cowles, T. J., Strickler, J. R. (1983). Characterization of feeding activity patterns in the planktonic copepod Centropages typicus Kroyer under various food conditions. Limnol. Oceanogr. 28: 106-115

Dagg, M. J. (1985). The effects of food limitation on diel migratory behavior in marine zooplankton. Arch. Hydrobiol. Beih. 21: 247-255

Dagg, M. J., Frost, B. W., Walser, W. E. Jr (1989). Copepod diel migration, feeding, and the vertical flux of pheopigments. Limnol. Oceanogr. 34: 1062-1071

Dagg, M. J., Grill, D. W. (1980). Natural feeding rates of Centropages typicus females in the New York Bight. Limnol. Oceanogr. 25: 597-609

Dagg, M. J., Walser, W. E. Jr (1987). Ingestion, gut passage, and egestion by the copepod Neocalanus plumchrus in the laboratory and in the subarctic Pacific Ocean. Limnol. Oceanogr. 32: 178-188

Dam, H. G., Peterson, W. T. (1988). The effect of temperature on the gut clearance rate constant of planktonic copepods. J. exp. mar. Biol. Ecol. 123: 1-14
Daro, M. H. (1980). Field study of the diel feeding of a population of Calanus finmarchicus at the end of a phytoplankton bloom. FLEX '76 22 May-5 June. 'Meteor' ForschErgebn. (A) 22: 123-132

Daro, M. H. (1985). Feeding rhythms and vertical migration of marine copepods. Bull. mar. Sci. 37: 487-497

Daro, M. H. (1988). Migratory and grazing behavior of copepods and vertical distribution of phytoplankton. Bull. mar. Sci. 43: 710-729

Deason, E. E. (1980a). Potential effect of phytoplankton colony breakage on the calculation of zooplankton filtration rates. Mar. Biol. 57: 279-286

Deason, E. E. (1980b). Grazing of Acartia hudsonica (A. clausi) on Skeletonema costatum in Narragansett Bay (USA): Influence of food concentration and temperature. Mar. Biol. 60: 101-113

Downs, J. N., Lorenzen, C. J. (1985). Carbon: pheopigment ratios of zooplankton fecal pellets as an index of herbivorous feeding. Limnol. Oceanogr. 30: 1024-1036

Durbin, E. G., Durbin, A. G. (1983). Energy and nitrogen budgets for the Atlantic menhaden, Brevoortia tyrannus (Pisces: Clupeidae), a filter-feeding planktivore. Fish. Bull. U.S. 81: 177-199

Durbin, E. G., Durbin, A. G., Smayda, T. J., Verity, P. G. (1983). Food limitation of production by adult Acartia tonsa in Narragansett Bay, Rhode Island. Limnol. Oceanogr. 28: 1199-1213

Elliott, J. M., Persson, L. (1978). The estimation of daily rates of food consumption for fish. J. Anim. Ecol. 47: 977-991

Ellis, S. G., Small, L. F. (1989). Comparison of gut-evacuation rates of feeding and non-feeding Calanus marshallae. Mar. Biol. 103: 175-181

Fancett, M. S., Kimmerer, W. J. (1985). Vertical migration of the demersal copepod Pseudodiaptomus as a means of predator avoidance. J. exp. mar. Biol. Ecol. 88: 31-43

Frost, B. W. (1972). Effects of size and concentration of food particles on the feeding behaviour of the marine planktonic copepod Calanus pacificus. Limnol. Oceanogr. 17: 805-815

Frost, B. W. (1977). Feeding behavior of Calanus pacificus in mixtures of food particles. Limnol. Oceanogr. 22: $472-491$

Frost, B. W. (1985). Food limitation of the planktonic marine copepods Calanus pacificus and Pseudocalanus sp. in a temperate fjord. Arch. Hydrobiol. Beih. 21: 1-13

Frost, B. W. (1988). Variability and possible adaptive significance of diel vertical migration in Calanus pacificus, a planktonic marine copepod. Bull. mar. Sci. 43: 675-694

Fuller, J. L. (1937). The feeding rate of Calanus finmarchicus in relation to environmental conditions. Biol. Bull. mar. biol. Lab., Woods Hole 72: 233-246

Gauld, D. T. (1953). Diurnal variations in the grazing of planktonic copepods. J. mar. biol. Ass. U.K. 31: 461-473

Gliwicz, M. A., Pijanowska, J. (1988). Effect of predation and resource depth distribution of vertical migration of zooplankton. Bull. mar. Sci. 43: 695-709

Guillard, R. R. L., Ryther, J. H. (1962). Studies of marine planktonic diatoms. I. Cyclotella nana Hustedt and Detonula confervacea (Cleve) Gran. Can. J. Microbiol. 8: 229-239

Hairston, N. G. (1979). The adaptive significance of color polymorphism in two species of Diaptomus (Copepoda). Limnol. Oceanogr. 24: 15-37

Haney, J. F. (1988). Diel patterns of zooplankton behavior. Bull. mar. Sci. 43: 583-603

Hansel, H. C., Duke, S. D., Lofy, P. T., Gray, G. A. (1988). Use of diagnostic bones to identify and estimate original 
lengths of ingested prey fishes. Trans. Am. Fish. Soc. 117: $55-62$

Harding, G. C., Vass, W. P., Hargrave, B. T. (1986). Diel vertical movements and feeding activity of zooplankton in St. Georges Bay, N.S., using net tows and a newly developed passive trap. Can. J. Fish. Aquat. Sci. 43: 952-967

Hattori, H. (1989). Bimodal vertical distribution and diel migration of copepods Metridia pacifica, M. okhotensis and Pleuromamma scutullata in the western North Pacific Ocean. Mar. Biol. 103: 39-50

Hayward, T. L. (1980). Spatial and temporal feeding patterns of copepods from the North Pacific Central Gyre. Mar. Biol. 58: 295-309

Head, E. J. H. (1986). Estimation of Arctic copepod grazing rates in vivo and comparison with in-vitro methods. Mar. Biol. 92: 371-379

Head, E. J. H. (1988). Copepod feeding behavior and the measurement of grazing rates in vivo and in vitro. Hydrobiologia 167/168: 31-41

Head, E. J. H., Harris, L. R., Abou Debs, C. (1985). Effect of daylength and food concentration on in situ diurnal feeding rhythms in Arctic copepods. Mar. Ecol. Prog. Ser. 24: 281-288

Head, E. J. H., Wang, R., Conover, R. J. (1984). Comparison of diurnal feeding rhythms in Temora longicornis and Centropages hamatus with digestive enzyme activity. J. Plankton Res. 6: 543-551

Helling, G. R., Baars, M. A. (1985). Changes of the concentrations of chlorophyll and phaeopigment in grazing experiments. Hydrobiol. Bull. 19: 41-48

Huntley, M., Brooks, E. R. (1982). Effects of age and food availability on diel vertical migration of Calanus pacificus. Mar. Biol. 71: 23-31

Johnsen, G. H., Jakobsen, P. J. (1987). The effect of food limitation on vertical migration in Daphnia longispina. Limnol. Oceanogr. 32: 873-880

Kiørboe, T., Møhlenberg, F., Riisgård, H. U. (1985). In situ feeding rates of planktonic copepods: a comparison of four methods. J. exp. mar. Biol. Ecol. 88: 67-81

Kiørboe, T., Møhlenberg, F., Hamburger, K. (1985). Bioenergetics of the planktonic copepod Acartia tonsa: Relation between feeding, egg production and respiration, and composition of specific dynamic action. Mar. Ecol. Prog. Ser. 26: 85-97

Kiørboe, T., Møhlenberg, F., Nicolajsen, N. (1982). Ingestion rate and gut clearance in the planktonic copepod Centropages hamatus (Lilljeborg) in relation to food concentration and temperature. Ophelia 21: 181-194

Kiørboe, T., Tiselius, P. T. (1987). Gut clearance and pigment destruction in a herbivorous copepod, Acartia tonsa, and the determination of in situ grazing rates. J. Plankton Res. 9: $525-534$

Kleppel, G. S., Willbanks, L., Pieper, R. E. (1985). Diel variation in body carotenoid content and feeding activity in marine zooplankton assemblages. J. Plankton Res. 7: 569-580

Kleppel, G. S., Pieper, R. E., Trager, G. (1988). Variability in the gut contents of individual Acartia tonsa from waters off southern California. Mar. Biol. 97: 185-190

Koehl, M. A., Strickler, J. R. (1981). Copepod feeding currents: food capture at low Reynolds number. Limnol. Oceanogr. 26: $1062-1073$

Lam, R. K., Frost, B. W. (1976). Model of copepod filtering response to changes in size and concentration of food. Limnol. Oceanogr. 21: 490-500

Lehman, J. T. (1976). The filter-feeder as an optimal forager, and the predicted shapes of feeding curves. Limnol. Oceanogr. 21: 501-516

Libourel Houde, S. E., Roman, M. R. (1987). Effects of food quality on the functional ingestion response of the copepod Acartia tonsa. Mar. Ecol. Prog. Ser. 40: 69-77

Mackas, D., Bohrer, R. (1976). Fluorescence analysis of zooplankton gut contents and an investigation of diel feeding patterns. J. exp. mar. Biol. Ecol. 25: 77-85

Mackas, D. L., Burns, K. E. (1986). Poststarvation feeding and swimming activity in Calanus pacificus and Metridia pacifica. Limnol. Oceanogr. 31: 383-392

MacLaren, I. A. (1963). Effects of temperature and growth of zooplankton, and the adaptive value of vertical migration. J. Fish. Res. Bd Can. 20: 685-727

Marshall, S. M., Orr, A. P. (1955). The biology of a marine copepod. Oliver \& Boyd, Edinburgh

Nicolajsen, H., Flemming, M., Kiørboe, T. (1983). Algal grazing by the planktonic copepods Centropages hamatus and Pseudocalanus sp.: diurnal and seasonal variation during the spring phytoplankton bloom in the Øresund. Ophelia 22: $15-31$

Nival, P., Nival, S. (1976). Particle retention efficiencies of an herbivorous copepod, Acartia clausi (adult and copepodite stages): effects on grazing. Limnol. Oceanogr. 21: 24-38

Nott, J. A., Corner, E. D. S., Mavin, L. J., O'Hara, S. C. M. (1985). Cyclical contributions of the digestive epithelium to faecal pellet formation by the copepod Calanus helgolandicus. Mar. Biol. 89: 271-279

Ohman, M. D. (1988). Sources of variability in measurements of copepod lipids and gut fluorescence in the California Current coastal zone. Mar. Ecol. Prog. Ser, 42: 143-153

Ohman, M. D., Frost, B. W., Cohen, E. B. (1983). Reverse diel vertical migration: an escape from invertebrate predators. Science 222: 1404-1407

Olson, R. J., Mullen, A. J. (1986). Recent developments for making gastric evacuation and daily ration determinations. Environ. Biol. Fishes 16: 183-191

Paffenhöfer, G.-A., Knowles, S. C. (1978). Feeding of marine planktonic copepods on mixed phytoplankton. Mar. Biol. 48: $143-152$

Paffenhöfer, G.-A., Stearns, D. E. (1988). Why is Acartia tonsa (Copepoda: Calanoida) restricted to nearshore environments? Mar. Ecol. Prog. Ser. 42: 33-38

Parsons, T. R., Maita, Y., Lalli, C. M. (1984). A manual of chemical and biological methods for seawater analysis. Pergamon, New York

Pasternak, A. F., Drits, A. V. (1988). Possible degradation of chlorophyll-derived pigments during gut passage of herbivorous copepods. Mar. Ecol. Prog. Ser. 49: 187-190

Piontkovskii, S. A., Petipa, T. S. (1976). Quantitative description of the behavior of copepod Acartia clausi during feeding on algae. Biol. Morja, Vladivostok (Soviet J. Mar. Biol.) 2: 40-46

Price, H. J., Paffenhöfer, G.-A., Strickler, J. R. (1983). Modes of cell capture in calanoid copepods. Limnol. Oceanogr. 28: 116-123

Price, H. J., Paffenhöfer, G.-A. (1986). Effects of concentration on the feeding of a marine copepod in algal monocultures and mixtures. J. Plankton Res. 8: 119-128

Ralston, M. L., Jennrich, R. I. (1979). DUD, a derivative-free algorithm for nonlinear least squares. Technometrics 1: 7-14

Ringelberg, J., Keyser, A. L., Flik, B. J. G. (1984). The mortality effect of ultraviolet radiation in a translucent and in a red morph of Acanthodiaptomus denticornis (Crustacea, Copepoda) and its possible ecological relevance. Hydrobiologia 112: 217-222 
Roman, M. R., Rublee, P. A. (1980). Containment effects in copepod grazing experiments: A plea to end the black box approach. Limnol. Oceanogr. 25: 982-990

Roman, M. R., Ashton, K. A., Gauzens, A. L. (1988). Day/night differences in the grazing impact of marine copepods. Hydrobiologia 167/168: 21-30

Rosenberg, G. G. (1980). Filmed observations of filter feeding in the marine plankton copepod Acartia clausii. Limnol. Oceanogr. 25: 738-742

Roy, S., Harris, R. P., Poulet, S. A. (1989). Inefficient feeding by Calanus helgolandicus and Temora longicornis on Coscinodiscus wailesii: quantitative estimation using chlorophyll-type pigments and effects on dissolved free amino acids. Mar. Ecol. Prog. Ser. 52: 145-153

Runge, J. A., Ingram, R. G. (1988). Underice grazing by planktonic, calanoid copepods in relation to a bloom of ice microalgae in southeastern Hudson Bay. Limnol. Oceanogr. 33: 280-286

Shuman, F, R., Lorenzen, C. J. (1975), Quantitative degradation of chlorophyll by a marine herbivore. Limnol. Oceanogr. 20: 580-586

Simard, Y., Lacroix, G., Legendre, L. (1985). In situ twilight grazing rhythm during diel vertical migrations of a scattering layer of Calanus finmarchicus. Limnol. Oceanogr. 30: 598-606

Sokal, R. R., Rohlf, F. J. (1969). Biometry. W. H. Freeman and Co., San Francisco

Sosnowski, S. L., Germond, D. J., Gentile, J. H. (1979). The effect of nutrition on the response of field populations of the calanoid copepod Acartia tonsa to copper. Wat. Res. 13: $449-452$

Stearns, D. E. (1986). Copepod grazing behavior in simulated natural light and its relation to nocturnal feeding. Mar. Ecol. Prog. Ser. 30: 65-76

Stearns, D. E., Forward, R. B. Jr (1984a). Photosensitivity of the calanoid copepod Acartia tonsa. Mar. Biol. 82: 85-89

Stearns, D. E., Forward, R. B. Jr (1984b). Copepod photobehavior in a simulated natural light environment and its

This article was presented by Professor G.-A. Paffenhöfer, Savannah, Georgia, USA relation to nocturnal vertical migration. Mar. Biol. 82: 91-100

Stearns, D. E., Litaker, W., Rosenberg, G. (1987). Impacts of zooplankton grazing and excretion on short-interval fluctuations in chlorophyll $a$ and nitrogen concentrations in a well-mixed estuary. Estuar. Coast. Shelf Sci. 24: 305-325

Tande, K. S., Slagstad, D. (1985). Assimilation efficiency in heribivorous aquatic organisms - The potential of the ratio method using ${ }^{14} \mathrm{C}$ and biogenic silica as markers. Limnol. Oceanogr. 30: 1093-1099

Tiselius, P. (1988). Effects of diurnal feeding rhythms, species composition and vertical migration on the grazing impact of calanoid copepods in the Skagerrak and Kattegat. Ophelia 28: 215-230

Wang, R., Conover, R. J. (1986). Dynamics of gut pigment in the copepod Temora longicornis (Muller) and the determination of in situ grazing rates. Limnol. Oceanogr. 31: 867-877

Ware, D. M. (1975). Growth, metabolism, and optimal swimming speed of a pelagic fish. J. Fish. Res. Bd Can, 32: 33-41

Williams, R. (1988). Spatial heterogeneity and niche differentiation in oceanic zooplankton. Hydrobiologia 167/168: 151-159

Williams, R., Conway, D. V. P. (1984). Vertical distribution, and seasonal and diurnal migration of Calanus helgolandicus in the Celtic Sea. Mar. Biol. 79: 63-73

Wimpenny, R. S. (1938). Diurnal variation in the feeding and breeding of zooplankton related to the numerical balance of the zoo-phytoplankton community. J. Cons. Int. Explor. Mer 13: 323-337

Wlodarczyk, E. (1988). Diel feeding, threshold feeding, and gut evacuation rate in the marine copepod Acartia hudsonica from Narragansett Bay, Rhode Island. M.S. thesis, University of Rhode Island

Zaret, T. M., Suffern, J. S. (1976). Vertical migration in zooplankton as a predator avoidance mechanism. Limnol. Oceanogr. 21: 804-813

Manuscript first received: October 15, 1988

Revised version accepted: July 20, 1990 